\title{
Conceptual Design, Sizing and Performance Analysis of a Cryo-Electric Propulsion System for a Next-Generation Hydrogen-Powered Aircraft
}

\author{
Christian Hartmann, Jonas Kristiansen Nøland, Robert Nilssen, and Runar Mellerud
}

\begin{abstract}
In this paper, we present a comprehensive sizing and performance analysis framework for a disruptive cryoelectric propulsion system intended for a hydrogen-powered regional aircraft. The main innovation lies in the systematic treatment of all the electrical and thermal components to model the overall system performance. One of the main objectives is to study the feasibility of using the liquid hydrogen $\left(\mathrm{LH}_{2}\right)$ fuel to provide cryogenic cooling to the electric propulsion system, and thereby enable ultra-compact designs. Another aim has been to identify the optimal working point of the fuel cell to minimize the overall propulsion system's mass. The full mission profile is evaluated to make the analysis as realistic as possible. Analyses are done for three different $\mathbf{2 0 3 5}$ scenarios, where available data from the literature are projected to a baseline, conservative, and optimistic scenario. The analysis shows that the total propulsion system's power density can be as high as $1.63 \mathrm{~kW} / \mathrm{kg}$ in the optimistic scenario and $0.79 \mathrm{~kW} / \mathrm{kg}$ in the baseline scenario. In the optimistic scenario, there is also sufficient cryogenic cooling capacity in the hydrogen to secure proper conditions for all components, whereas the DC/DC converter falls outside the defined limit of $110 \mathrm{~K}$ in the baseline scenario.
\end{abstract}

Index Terms-Fuel cells, hydrogen-powered aviation, cryoelectric propulsion, superconducting machines, cold power electronics, thermal modeling, HTS cables, regional aircraft.

\section{NOMENCLATURE}

Symbols

$A_{F C, e f f}$

$a_{p o l}, b_{p o l}$

$c_{p, \text { air }}$

F

$h$

$\Delta h_{H_{2}, H H V}$

$j_{\text {cell }}$

$k_{1}$

$m$

$\dot{m}$

$M_{\text {air }}$

$M a$

$n$

$p$

$p_{0}$

$p q_{T M S}$

$P$

$P F$

$P T W$

$q m_{T M S}$
Fuel cell total effective area, $\left[\mathrm{m}^{2}\right]$

Coefficients in linear approximation of polarization voltage, $\left[\mathrm{Vcm}^{2} / \mathrm{A}\right],[\mathrm{V}]$

Specific heat capacity of air, $1.0 \mathrm{~kJ} /(\mathrm{kg} \cdot \mathrm{K})$

Faraday's constant, $96485 \mathrm{C} / \mathrm{mol}$

Specific enthalpy, [J/kg] \& altitude, $[\mathrm{m}]$

Higher heating value of $\mathrm{H}_{2}, 1.418 \cdot 10^{5}$

$\mathrm{kJ} / \mathrm{kg}$

Fuel cell current density, $\left[\mathrm{A} / \mathrm{cm}^{2}\right]$

constant in expression for $\mathrm{T}_{\mathrm{amb}}, 42361 \mathrm{~m}$

Mass, [kg]

Mass flow, $[\mathrm{kg} / \mathrm{s}]$

Molar mass of air, $28.9646431 \mathrm{~g} / \mathrm{mol}$

Mach number, [-]

Rotational speed [rpm]

Pressure, [Pa]

Ambient pressure at MSL, $101324 \mathrm{~Pa}$

TMS power consumption per unit heat load removed, [-]

Power, [W]

Power factor, [-]

Power-to-weight ratio, $[\mathrm{kW} / \mathrm{kg}]$

Inverse specific weight of TMS, $[\mathrm{kJ} /(\mathrm{s} \cdot \mathrm{kg})]$
$\dot{Q}$

$R_{s p, a i r}$

$\Delta T_{I S A}$

$T$

$T_{0}$

$T T W$

$U$

$x_{\mathrm{O}_{2}}$

Greek letters

$\eta$

$\eta_{\text {comp,el }}$

$\eta_{c o m p, m}$

$\eta_{c o m p, p c}$

$\eta_{c o m p, s}$

$\eta_{p r}$

$\gamma_{\text {air }}$

$\lambda$

$\lambda_{H_{2}, \text { net }}, \lambda_{O_{2}}$

$\rho$

Subscripts

amb

aux

avg

BoP

cell

c

comp

DCAC

DCDC

eff

el

exh

FC

FCHX

HHV

HTS

hum

in

$\max$

out

prop

SCM

stack

stat
Heat load, [J/s]

Specific gas constant of air, 0.28704 $\mathrm{kJ} /(\mathrm{kg} \cdot \mathrm{K})$

Temperature difference from ISA at MSL, $24 \mathrm{~K}$

Temperature, [K]

Ambient temperature at MSL, 288.15 K

Torque-to-weight ratio, $[\mathrm{Nm} / \mathrm{kg}]$

Voltage, [V]

Molar fraction of $\mathrm{O}_{2}$ in air, 0.209

\section{Efficiency [-]}

Compressor motor efficiency, 0.94 [1]

Mechanical compressor efficiency, 0.97

[1]

Compressor converter efficiency, 0.95 [1]

Isentropic compressor efficiency, 0.76 [1]

Pressure recovery, 0.75 [1]

Ratio of specific heats for air, 1.4

Used for ratios, [-]

Stoichiometric ratios for $\mathrm{H}_{2}$ and $\mathrm{O}_{2},[-]$

Mass density, $[\mathrm{kg} / \mathrm{m}],\left[\mathrm{kg} / \mathrm{m}^{2}\right],[\mathrm{kg} / \mathrm{kW}]$, $[\mathrm{kg} /(\mathrm{kg} / \mathrm{s})]$

Ambient

Fuel cell auxiliary components

Average

Balance of plant

Single fuel cell

Cold

Compressor

DC/AC motor inverter

DC/DC converter

Effective

Electrical

Exhaust

Fuel cell

Fuel cell heat exchanger

Higher heating value

High temperature superconductor

Humidifier

Inlet

Maximum

Outlet

Propeller

Superconducting motor

Fuel cell stack

Static 
Total

Warm

\section{INTRODUCTION}

$\mathbf{H}$ YDROGEN-POWERED aviation has received a renewed interest over the last few years due to its attractive promises of decarbonizing air transport [2]. There is also a push to utilize hydrogen as a sustainable fuel in other sectors as well, including hydrogen fuel cell vehicles (FCVs) [3], hydrogen trains (hyrail) [4], hybrid fuels cells in marine vessels [5], to name a few.

In general, the energy density of the onboard energy storage is seen as the main limiting factor to scale up climate-neutral aviation for battery-electric architectures [6]. However, hydrogen is a much lighter energy source for aviation [2]. Hydrogen-powered aviation is also desired to be fully electric to not only deal with $\mathrm{CO}_{2}$ emissions but also non- $\mathrm{CO}_{2}$ emissions. A further step is to make the propulsion system cryo-electric, where the hydrogen fuel is stored as liquid hydrogen $\left(\mathrm{LH}_{2}\right)$ and used for both electric power generation and for cooling of the electrical components. Due to the cryogenic temperature of the $\mathrm{LH}_{2}$, the electrical machine and power transmission systems can be made superconducting, which is projected to dramatically reduce the size of the propulsion system [7], without the need to add weightintensive cryocoolers. Another way to cut aircraft weight is to pursue multi-functional (MF) materials, integrating both mechanical and electrical properties [8].

In this study, we investigate a hydrogen-powered cryoelectric propulsion system where a proton-exchange membrane fuel cell (PEMFC) provides electrical energy to feed superconducting motors (SCMs) for propulsion. The hydrogen that goes into the PEMFC is also used for cryogenic cooling of the SCMs and high-temperature superconducting (HTS) cables, and furthermore to provide cryogenic conditions for cold power electronics (CPE). In this way, it is possible to minimize or fully eliminate the cryocoolers, which would otherwise be necessary to cool the components. Cryocoolers represent a significant mass and efficiency penalty to superconducting energy conversion systems [9].

One of the main scientific questions we seek to answer is whether there is an energy balance between the hydrogen consumption in the fuel cell and the heat loads in the cryogenic cooling loop at all operating points during a flight mission of a typical regional aircraft.

Numerous studies have been performed on the components that together constitute the full system [1], [9]-[12], but these studies are either conducted on other system architectures or on single components that overlooks the important system considerations. The concept of using hydrogen for cryogenic cooling has also been investigated in detailed studies, e.g. [13]. These studies provide important insights into the concepts and mechanisms of the system we want to investigate, but they do not provide a sufficient basis for understanding the interdependencies between the components and the cooling system.

The main contribution of this paper lies in the comprehensive framework where the component sizing and operation points of a cryogenic propulsion system for a next-generation hydrogen-powered aircraft are analyzed as a whole.

The present paper is organized with the following structure. First, the objective and the scope of the study are described in Section II. Next, Section III describes the mission profile considered and the ambient conditions. Then, the cryo-electric architecture is described in detail in Section IV, before the complete model framework is comprehensively described in Section V. Finally, the model implementation and analysis of the results from the simulated scenarios are presented in Section VI.

\section{OBJECTIVE AND SCOPE}

The work presented herein investigates the cryo-electric architecture in Fig. 1. It is electrified by a hydrogen-fueled PEMFC, providing power downstream to a superconducting motor (SCM). The power to the motor is transmitted via high-temperature superconductors (HTS), with cold power electronic (CPE) converters in each end. Finally, the SCM drives a propeller, either directly or via a gearbox. Both configurations will be explored in this study. The hydrogen fuel is stored as a liquid $\left(\mathrm{LH}_{2}\right)$ at $20 \mathrm{~K}$.

The main objectives of the study are as follows.

1) Investigate if and to what extent the $\mathrm{LH}_{2}$ fuel can also be utilized for cryogenic cooling of superconductors and cold power electronics onboard and at all modes of operation, and;

2) Analyse if the system in Fig. 1 can be realized with sufficient power density to enable the cryo-electric propulsion concept to be scalable.

In Table I, the main objectives are quantified in detail. The superconductors and converters dictate the maximum allowable hydrogen temperatures. The power-to-weight (PTW) target for the system inside the model boundary in Fig. $1, P T W_{t o t}$, is set in accordance with up-to-date aviation industry targets. This is ambitious because aerospace-grade fuel cells cannot be trusted to achieve more than $1 \mathrm{~kW} / \mathrm{kg}$ in the present, which is currently the bottleneck of hydrogenelectric propulsion systems. However, technology experts believe that fuel cell power densities of $4 \mathrm{~kW} / \mathrm{kg}$ could be possible by 2024 [14].

TABLE I

TARGET VALUES FOR COMPLETE CRYO-ELECTRIC PROPULSION SYSTEM

\begin{tabular}{ll}
\hline \hline Objective & Target \\
\hline & $T_{S C M, \max }<25 \mathrm{~K}\left(\mathrm{MgB}_{2}\right)$ \\
Utilize $\mathrm{LH}_{2}$ fuel & or $T_{S C M, \max }<60 \mathrm{~K}(\mathrm{REBCO})$ \\
for cryocooling & $T_{H T S, \max }<77 \mathrm{~K}$ \\
& $T_{D C A C, \max }<110 \mathrm{~K}$ \\
& $T_{D C D C, \max }<110 \mathrm{~K}$ \\
\hline Power density & $P T W_{\text {tot }}>1 \mathrm{~kW} / \mathrm{kg}$ \\
\hline
\end{tabular}

As of today, the technologies involved have not reached readiness levels (TRLs) where they can be considered for aircraft applications. It is therefore attempted to project results and trends reported in the literature to a 2035 scenario. To account for the difficulties and inevitable errors in predicting 


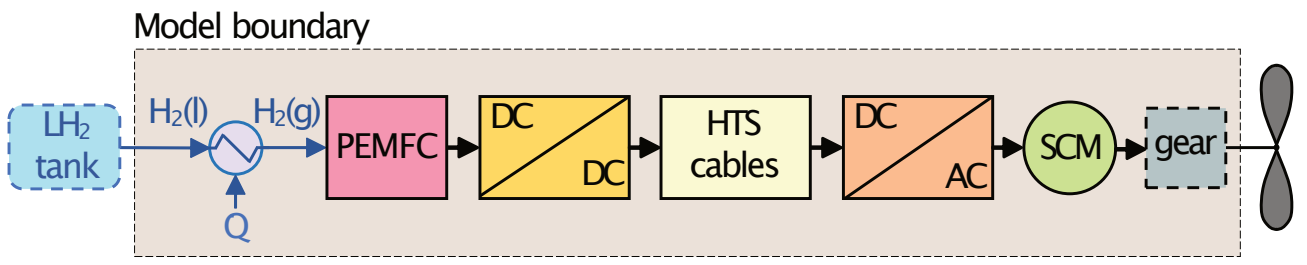

Fig. 1. Principal arrangement of the system investigated herein, where the PEMFC is the proton-exchange membrane fuel cell, the HTS cables are high-temperature superconducting, and the SCM is a superconducting machine.

future performance data, we operate with three different 2035 scenarios, i.e., a conservative, an optimistic, and a baseline scenario, respectively. In general, the conservative and optimistic scenarios represent what is believed to be the worst and best interpretations of available data. The baseline values are set near the middle of the two extremes.

The boundary of the system model is classified in Fig. 1. The only energy source in the system is the $\mathrm{LH}_{2}$, and the SCMs consume all net output power from the PEMFC. There are no energy buffers, so all required power is assumed to be instantly available from the PEMFC. Start-up and transient behavior are not considered. Each point of operation through the flight mission is modeled as in steady-state. With the exception of the PEMFC, all components are modeled as having fixed efficiencies that do not vary over the operation points. Moreover, the system has no redundancy or protection systems.

The system is rated for a total power of $4.1 \mathrm{MW}$, suitable for a twin-engine single-aisle 70-seater aircraft [15]. The aircraft data is very similar to that of an ATR 72-600; see Table II.

TABLE II

AIRCRAFT DATA

\begin{tabular}{lcccc}
\hline \hline PAX & $\begin{array}{c}\text { Max. } \\
\text { range }\end{array}$ & $\begin{array}{c}\text { Max. total } \\
\text { motor power }\end{array}$ & $\begin{array}{c}\text { Max. propeller } \\
\text { speed }\end{array}$ & MTOW \\
\hline 70 & $1200 \mathrm{~km}$ & $\begin{array}{c}4.1 \mathrm{MW} \\
(2 \cdot 2.05 \mathrm{MW})\end{array}$ & $1200 \mathrm{rpm}$ & $23000 \mathrm{~kg}$ \\
\hline \hline
\end{tabular}

\section{MISSION PROFILE AND ATMOSPHERIC CONDITIONS}

The mission profile and atmospheric conditions have a significant impact on the rating of the components. A detailed mission profile for the hybrid-electric regional aircraft in Table II has been developed by Jux et al. [15]. It is adopted in this work due to its relevant and detailed power profile. The altitude and speed profiles have been simplified by dividing the mission phases into piecewise linear segments. The resulting mission profile is shown in Fig. 2.

The International Standard Atmosphere (ISA) defines ambient pressure and temperature expressions as a function of elevation above mean sea level (MSL), as mathematically described in eqs. (1) and (2). These will be used to obtain valuable atmospheric information from the mission profile in Fig. 2 to be used in the fuel cell modeling in Section V-H. The ISA models [16] assume an ambient temperature $T_{0}=288.15$ $\mathrm{K}\left(15^{\circ} \mathrm{C}\right)$ at MSL. As this temperature is not representative of hot day conditions, it is necessary to make a correction on it. The last term in eq. (2) has been added to yield results consistent with the "hot" non-standard atmosphere defined in MIL-STD-210A [17], [18] in the altitude range 0-6500 $\mathrm{m}$. Finally, $\Delta T_{I S A}$ is set to $24 \mathrm{~K}$, which yields a temperature of $39{ }^{\circ} \mathrm{C}$ at MSL.

$$
\begin{gathered}
p_{a m b}=p_{0}\left(1-0.0065 \cdot \frac{h}{T_{0}}\right)^{5.2561} \\
T_{a m b}=T_{0}-6.5 \frac{h}{1000}+\Delta T_{I S A}\left(1-\frac{h}{k_{1}}\right)
\end{gathered}
$$

\section{Cryo-Electric Propulsion System}

This section describes the key components in the considered cryo-electric propulsion system, including thermal management systems (TMS), cryogenic cooling loops, and heat exchange dynamics with hydrogen.

\section{A. Breakdown of All Energy Flows}

Fig. 3 shows the system model with cooling circuits, TMS, and a fuel cell compressor included. The blue cooling circuit shows how the hydrogen fuel is directed to provide cryogenic cooling of the SCM, HTS cables, and the power electronics before it enters the fuel cell.

Since hydrogen fuel does not have sufficient heat capacity to take out all the losses in the system, an additional conventional cooling circuit is required. This is the TMS circuit, drawn with arrows in orange in Fig. 3. It is mainly the heat loads from the PEMFC that go into the TMS, but noncryogenic heat loads from the SCM and gear (when included) also contribute. It is worth noting that the TMS consumes electrical power to do this essential work.

A compressor is required to compress the ambient air before it is fed into the PEMFC's cathode. The airflow is drawn in gray in Fig. 3. Since the temperature of the air increases as it is compressed, it is also necessary to have a heat exchanger where the excess heat built up over the compressor can be removed in order to maintain optimum air temperature at the cathode inlet.

It can be seen from Fig. 3 that the DC/DC converter must be dimensioned to supply power to the compressor and the TMS in addition to the power delivered to the SCM.

In this study, the hydrogen supplied from the tank is modeled as being either fully liquid at $20 \mathrm{~K}$ or saturated vapor at $22.164 \mathrm{~K}$.

\section{B. Cryogenic Cooling Loop}

One of the main objectives of this study is to investigate the feasibility of using the $\mathrm{LH}_{2}$ fuel to provide cryogenic cooling of superconductors and power electronic components. There 


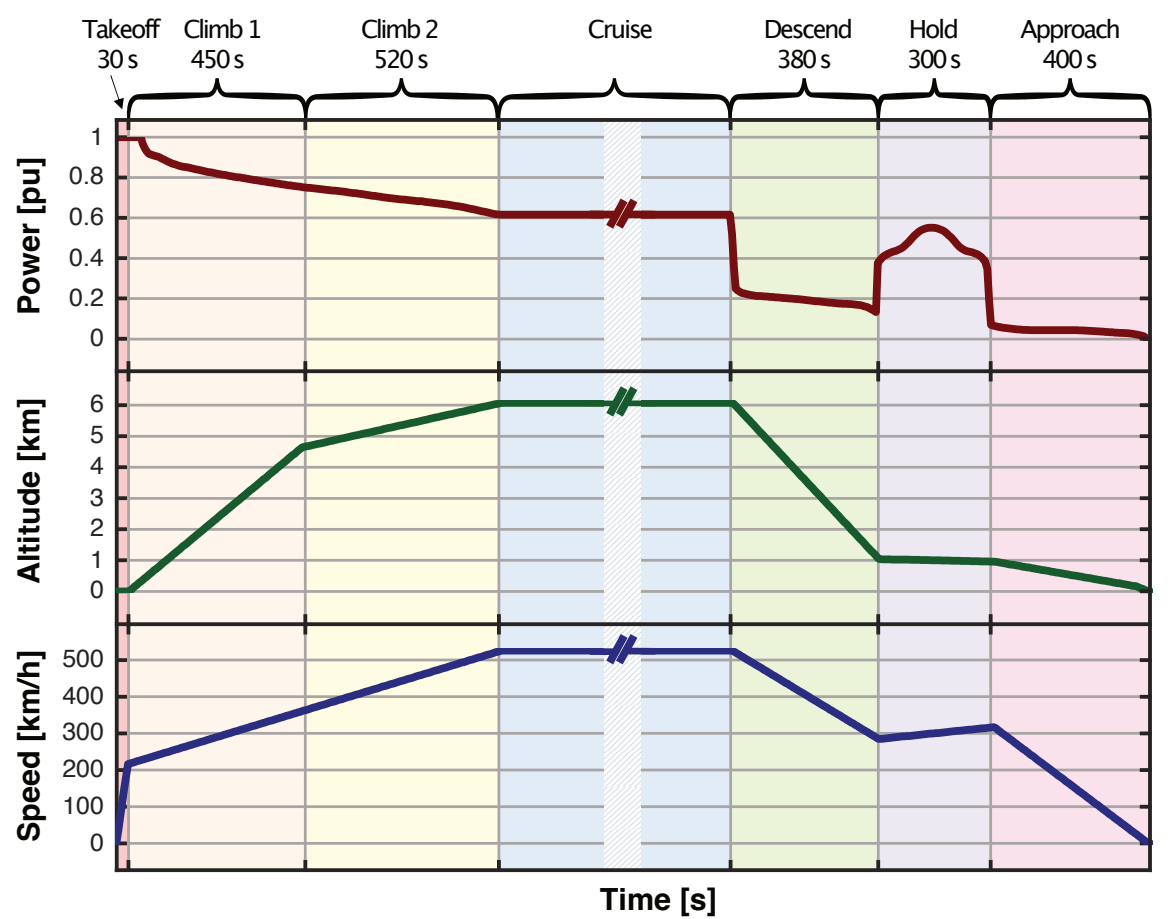

Fig. 2. A complete mission profile adopted from Jux et al. [15], for power, altitude, and speed. Base power is $4.1 \mathrm{MW}$ per unit (pu).

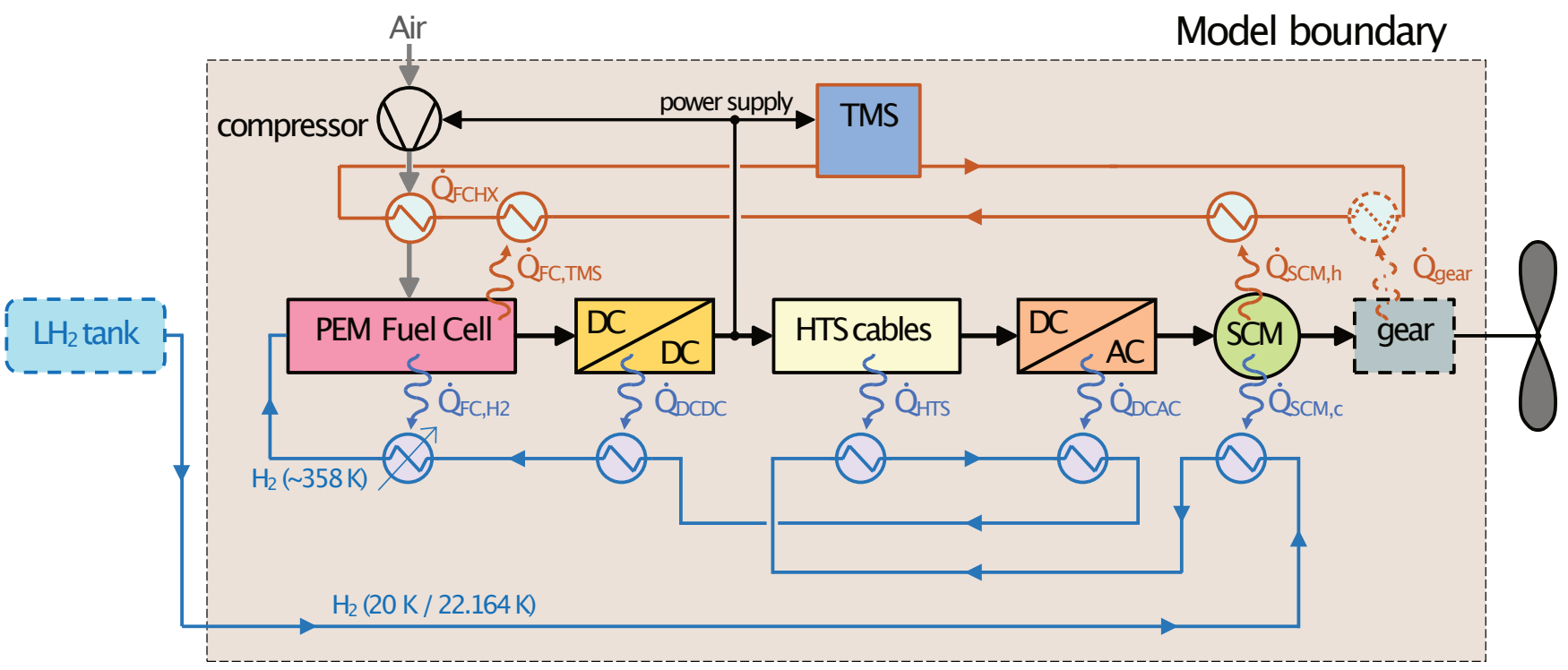

Fig. 3. A more detailed representation of Fig. 1 including the model of the cooling arrangements, the thermal management system (TMS) and the fuel cell compressor, respectively.

is a very valuable synergy if this can be achieved. Firstly, it enables the use of highly compact and efficient SCMs, HTS transmission, and cold power electronics. Secondly, the cryocoolers that otherwise would be required to cool the superconductors can be eliminated or minimized, which means large savings in weight and power consumption. Thirdly, it becomes unnecessary to have an extra heat exchanger between the $\mathrm{LH}_{2}$ tank and the PEMFC.

It is imperative that the cryogenic temperatures stay strictly within limits dictated by the types of superconductors used in the SCM and the HTS cables. For the SCM, this temperature limit is set either to $25 \mathrm{~K}$ or $60 \mathrm{~K}$, depending on whether $\mathrm{MgB}_{2}$ or REBCO is used. It is assumed that REBCO is used for the HTS cables and that they can be operated at temperatures up to $77 \mathrm{~K}$ due to the very small losses.

It has also been reported that power electronic components can be made much more compact and efficient if they are allowed to operate at cryogenic temperatures. The operational temperature limit for cold power electronics does not seem to be exactly defined. Here, $110 \mathrm{~K}$ will be used as an indicative value [13], but unlike superconductors, there is no abrupt and detrimental transition if this temperature is exceeded.

After heat from the superconductors and power electronics have been absorbed by the hydrogen, the remaining heat required to bring the hydrogen to $85{ }^{\circ} \mathrm{C}$ (inlet temperature at the PEMFC) is absorbed from the heat-loss in the PEMFC. As mentioned previously, this heat only constitutes a small 
fraction of the total heat produced in the PEMFC. The remaining heat-loss needs to be removed by the TMS, as illustrated in Fig. 3.

The cryogenic cooling loop from Fig. 3 is redrawn in Fig. 4 with the components arranged in the sequence in which they exchange heat with the hydrogen. The temperature limits are also defined in the figure.

\section{Heat Exchange With Hydrogen}

Hydrogen has a high heat capacity which makes it an excellent cryogenic coolant. The specific heat capacity is about $12 \mathrm{~kJ} /(\mathrm{kg} \cdot \mathrm{K})$, but this value varies over the temperature range being studied. For this reason, it is convenient to use the specific enthalpy of hydrogen to determine the temperature increase as a function of loss-heat absorbed by the hydrogen. Enthalpy tables are provided on the website of the National Institute of Standards and Technology (NIST) [19].

The hydrogen-cooled components are modeled as control volumes. When subjected to a constant hydrogen mass flow $\dot{m}_{H 2}$ and heat influx $\dot{Q}$ the temperature rise is related to to the change in enthalpy over the components; see Fig. 5, and eqs. (3) and (4). It is assumed that the only heat $\dot{Q}$ transferred to the hydrogen originates from the heat-losses generated in the components.

$$
\begin{gathered}
h\left(T_{2}\right)=h\left(T_{1}\right)+\frac{\dot{Q}}{\dot{m}_{H_{2}}} \\
T_{2}=T\left(h_{2}\right)
\end{gathered}
$$

The hydrogen pressure is set equal to the PEMFC anode pressure (1.66 bar). For simplicity, the pressure drop over the components is neglected.

In the models, the hydrogen can be either gaseous $\left(\mathrm{GH}_{2}\right)$ or liquid $\left(\mathrm{LH}_{2}\right)$ when it is fed into the cryogenic cooling circuit. In the cases where it is modeled as being liquid, it is necessary to take the hydrogen's latent heat of vaporization into account. During the phase-change at $22.164 \mathrm{~K}$, the hydrogen absorbs $438 \mathrm{~kJ} / \mathrm{kg}$ before it is fully vaporized. Such two-phase cooling significantly increases the cooling capacity of the cryogenic cooling loop compared to purely gaseous cooling.

\section{Model Framework For COMPOnEnt Sizing}

The framework for power and heat load balance as well as component sizing is further developed in this section.

\section{A. Component-Level Loss Modeling}

The sizing of the components is done in the upstream direction, starting with the gearbox. This is done to correctly account for the efficiency of the various components since each consecutive component must have a power rating sufficient to supply not only useful power but also the downstream losses.

Iteration is required to determine the power balance of the PEMFC and the compressor/TMS due to the components' interdependency. The description of how this balancing is done is deferred to Section VI-A when the simulation model is described.
The input power to a component is given by

$$
P_{\text {in }}=P_{\text {downstr }}+\dot{Q}_{\text {loss }}
$$

where

$$
\dot{Q}_{\text {loss }}=P_{\text {downstr }}\left(\frac{1}{\eta}-1\right) .
$$

Here, $P_{\text {downstr }}$ is the sum of useful power and accumulated losses of all components downstream. $\dot{Q}$ and $\eta$ are the loss and efficiency of the component being sized.

\section{B. Gearbox Sizing}

Connecting a gearbox between the SCM shaft and the propeller allows for choosing an SCM shaft speed different from the propeller speed. The benefit of this is that the mass and volume of the SCM can be reduced when it is designed for higher rotational speeds. However, some of this reduction will be offset by the mass and volume of the gearbox. Gearboxes also introduce increased loss in the system.

Eq. (7) is based on data from reference [20]. It estimates the gearbox mass as a function of the transmitted power and the speed (in rpm) of the SCM rotor and the propeller.

$$
m_{\text {gear }}=k_{\text {gear }} \frac{\left(P_{S C M}\right)^{0.76} \cdot\left(n_{S C M}\right)^{0.13}}{\left(n_{\text {prop }}\right)^{0.89}}
$$

A value of $k_{\text {gear }}=0.21$ gives results consistent with reference [20]. This is set as the baseline value. $20 \%$ mass is added and subtracted for the conservative and optimistic estimates, respectively.

The efficiency of the gearbox is dependent on the operating point. Boll et al. [10] reports efficiencies reaching $99.6 \%$, whereas other studies report lower efficiencies, in the range $96 \%-99 \%$ [9], [21].

Table III summarizes the gearbox parameters considered in this study.

TABLE III

SIMULATION PARAMETERS, GEARBOX

\begin{tabular}{lcccc}
\hline \hline \multirow{2}{*}{ Parameter } & \multirow{2}{*}{ Symbol } & \multicolumn{3}{c}{2035 scenario } \\
\cline { 3 - 5 } & & Conservative & Baseline & Optimistic \\
\hline Sizing factor [-] & $k_{\text {gear }}$ & 0.25 & 0.21 & 0.17 \\
Efficiency [\%] & $\eta_{\text {gear }}$ & 98.5 & 99.0 & 99.5 \\
\hline
\end{tabular}

\section{Superconducting Motor Sizing}

Table IV below summarizes the main results from two recent design studies performed on SCMs for aircraft applications. The first machine [10] is a fully superconducting propulsion motor. The second machine [12] is a generator with superconducting distributed field coils in the rotor and conventional copper armature windings on the stator.

Both studies report a significant loss increase with increasing frequency. Therefore, the maximum speed is limited to either $1200 \mathrm{rpm}$ (direct-drive) or $3500 \mathrm{rpm}$ (geared drive) in the model simulations. Since the maximum speed is varied, the torque-to-weight (TTW) ratio is used to size the machines. The power-to-weight (PTW) ratio can be found from eq. (8). 


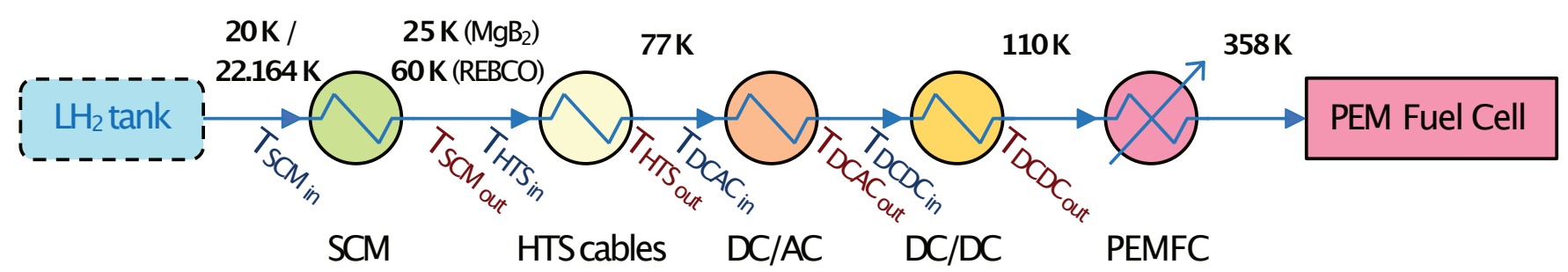

Fig. 4. Sequence of components arranged according to the flow of cryogenic coolant from the $\mathrm{LH}_{2}$ tank to the PEM fuel cell.

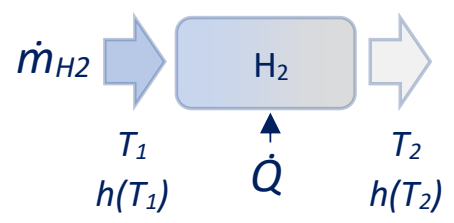

Fig. 5. Hydrogen mass flow through a control volume with heat input $\dot{Q}$ to the medium between two temperature levels $\left(T_{1}\right.$ and $\left.T_{2}\right)$.

TABLE IV

RECENT SCM REFERENCE STUDIES

\begin{tabular}{lcc}
\hline \hline & \multicolumn{2}{c}{ Study } \\
\cline { 2 - 3 } & Boll et al. [10] & Filipenko et al. [12] \\
\hline SCM type & Fully SC & Partially SC (SC rotor) \\
Power [MW] & 10.5 & 10.0 \\
Speed [rpm] & 3500 & 7000 \\
El. frequency [Hz] & 350 & 467 \\
Power factor [-] & - & 0.89 \\
Heat load to cryogen [kJ/s] & 2.40 & 0.07 \\
Heat load to TMS [kJ/s] & 5.68 & 200 \\
Efficiency [\%] & 99.92 & 98.00 \\
Weight [kg] & 303 & 500 \\
PTW [kW/kg] & 34.7 & 20 \\
TTW [Nm/kg] & 94.5 & 27.3 \\
\hline \hline
\end{tabular}

$$
P T W_{S C M}=\frac{\pi}{30} n_{S C M} T T W_{S C M} \cdot 10^{-3}
$$

The three simulation scenarios for the SCM are set with quite a wide span between the conservative and the optimistic scenario. This is to account for the possibility of using different SCM topologies (fully superconducting, partially superconducting, yokeless, etc.). The SCM parameters will also be investigated individually in a sensitivity study to gain an understanding of how the SCM parameters impact the total system.

In Table V, the motor efficiency is split into a "cold" and a "warm" contribution. This is done to separate the losses discharged to the cryogenic cooling loop and the TMS cooling loop. The total efficiency of the motor is given by

$$
\eta_{S C M, t o t}=\frac{1}{\frac{1}{\eta_{S C M, c}}+\frac{1}{\eta_{S C M, w}}-1} .
$$

TABLE V

SIMULATION PARAMETERS, SCM

\begin{tabular}{lcccc}
\hline \hline \multirow{2}{*}{ Parameter } & \multirow{2}{*}{ Symbol } & \multicolumn{3}{c}{ 2035 scenario } \\
\cline { 3 - 5 } & & Conservative & Baseline & Optimistic \\
\hline TTW [Nm/kg] & $T T W_{S C M}$ & 30 & 60 & 90 \\
"Cold" efficiency [\%] & $\eta_{S C M, c}$ & 99.0 & 99.5 & 99.9 \\
"Warm" efficiency [\%] & $\eta_{S C M, w}$ & 98.0 & 99.0 & 99.5 \\
Power factor [-] & $P F_{S C M}$ & 0.80 & 0.89 & 0.92 \\
Speed [rpm] & $n_{S C M}$ & $1200 / 3500$ & $1200 / 3500$ & $1200 / 3500$ \\
\hline \hline
\end{tabular}

\section{DC/AC Motor Inverter Sizing}

Various performance metrics for cold power electronic motor inverters have been reported. The PTW ratios span from $19 \mathrm{~kW} / \mathrm{kg}$ [10] to $30 \mathrm{~kW} / \mathrm{kg}$ [11], whereas the efficiencies are in the range $99.3 \%$ [22] to $99.98 \%$ [10].

Boeing has set target values of $99.3 \%$ efficiency and a power-to-weight ratio of $26 \mathrm{~kW} / \mathrm{kg}$ for the development of a $1 \mathrm{MW}$ cryogenic motor inverter operating at $1000 \mathrm{~V}$ input voltage [23]. The baseline scenario is set close to these values.

TABLE VI

SIMULATION PARAMETERS, DC/AC MOTOR INVERTER

\begin{tabular}{lcccc}
\hline \hline \multirow{2}{*}{ Parameter } & \multirow{2}{*}{ Symbol } & \multicolumn{3}{c}{2035 scenario } \\
\cline { 3 - 5 } & & Conservative & Baseline & Optimistic \\
\hline PTW [kW/kg] & $P T W_{D C A C}$ & 20 & 25 & 35 \\
Efficiency [\%] & $\eta_{D C A C}$ & 99.0 & 99.3 & 99.8 \\
\hline \hline
\end{tabular}

The apparent power of the SCM must be accounted for in determining the inverter mass and loss, yielding

$$
\begin{gathered}
m_{D C A C}=\frac{P_{i n, S C M}}{P F_{S C M} P T W_{D C A C}}, \\
\dot{Q}_{D C A C}=\frac{P_{i n, S C M}}{P F_{S C M}}\left(\frac{1}{\eta_{D C A C}}-1\right) .
\end{gathered}
$$

It follows from this that the efficiency seen from the input will be lower than $\eta_{D C A C}$. The input must supply the extra losses originating from the reactive currents. The de-facto efficiency is reduced as a consequence of this. The efficiency seen from the input becomes

$$
\eta_{D C A C}^{\prime}=\frac{P F_{S C M}}{\frac{1}{\eta_{D C A C}}-1+P F_{S C M}} .
$$

\section{E. HTS Cable Sizing}

The specific weight of DC HTS cables reported in the literature lies in the range $5-14 \mathrm{~kg} / \mathrm{m} \mathrm{[10],} \mathrm{[24]-[26].} \mathrm{The} \mathrm{power}$ 
levels in these studies are higher than what is considered here. The HTS cryostat needs to be well-insulated to minimize heat leaks. This requirement is relatively independent of the power transfer. However, the voltage and current loading have an impact on the mass of the HTS conduit since both these parameters dictate pole-to-pole and pole-to-ground distances [10]. In light of this, $5 \mathrm{~kg} / \mathrm{m}$ seems like a reasonable baseline value for the specific weight of each HTS conduit.

The reference aircraft (ATR 72-600) has a length of 27 $\mathrm{m}$ and a wingspan of $27 \mathrm{~m}$. The distance between the $\mathrm{DC} / \mathrm{DC}$ converter and the motor inverter is roughly estimated to be one-quarter of the aircraft length and one-quarter of the wingspan. Hence, the required HTS cabling for each motor is $13.5 \mathrm{~m}$, such that the total HTS cable length is $27 \mathrm{~m}$. This is a very coarse but conservative length estimate.

TABLE VII

SimUlation PARAMETERS, HTS CABLES

\begin{tabular}{lcccc}
\hline \hline \multirow{2}{*}{ Parameter } & \multirow{2}{*}{ Symbol } & \multicolumn{3}{c}{2035 scenario } \\
\cline { 3 - 5 } & & Conservative & Baseline & Optimistic \\
\hline HTS specific mass [kg/m] & $\rho_{H T S}$ & 10 & 5 & 3 \\
HTS total mass [kg] & $m_{H T S}$ & 270 & 135 & 81 \\
Efficiency [\%] & $\eta_{H T S}$ & 99.9 & 99.95 & 99.99 \\
\hline \hline
\end{tabular}

\section{F. Thermal Management System Sizing}

Heat losses that are not absorbed by the hydrogen fuel must be removed by the TMS.

Although electric components are characterized by high efficiencies, they also have some inherent drawbacks when it comes to thermal management. The maximum admissible operating temperatures for most electrical components are low. This makes heat transfer and heat rejection costly since the mass and volume of key TMS components such as heat exchangers, cold plates, etc., need to be large to compensate for the low-temperature differentials.

Electrical components must also be protected from particles and moisture. This reduces the ability to exchange heat with the surroundings.

The fact that the components' heat loads are at their highest at the beginning of take-off poses a special challenge [18], [27]. At this mission point, the ambient temperature is high, whereas the velocity of the surrounding air relative to the aircraft is low. Without a means to increase the velocity of the air passing through the heat exchanger, the TMS can become excessively bulky. A ram air-based TMS has been investigated in several studies [18], [22], [27], [28]. In this arrangement, the air is channeled through a heat exchanger (HX), and its velocity is maintained by a ram fan. The principal arrangement is outlined in Fig. 6.

TMS performance data have been collected from 5 studies. The results are summarized in Table VIII.

The key metrics in Table VIII are listed in columns 5 and 6, where $\dot{Q}_{T M S, \max } / m_{T M S}$ specifies the maximum heatloss that can be removed per kilogram of TMS system. Moreover, $P_{T M S, \max } / \dot{Q}_{T M S, \max }$ specifies the TMS's power consumption per $\mathrm{kJ} / \mathrm{s}$ of removed heat load.

In general, there is a relatively large spread in the performance values given in Table VIII. The authors of these

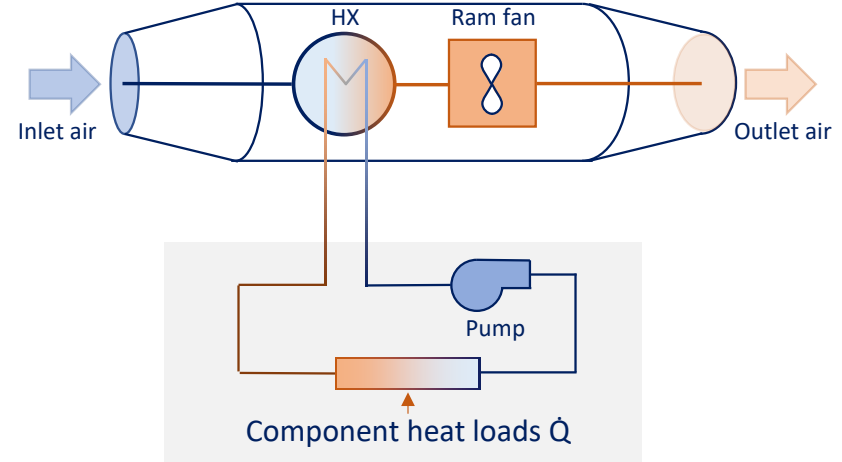

Fig. 6. Ram air-based thermal management system

TABLE VIII

TMS PERFORMANCE DATA FROM 5 AVAILABLE STUDIES

\begin{tabular}{lccccc}
\hline \hline Study & $\begin{array}{c}m_{T M S} \\
{[\mathrm{~kg}]}\end{array}$ & $\begin{array}{c}P_{T M S, \max } \\
{[\mathrm{kW}]}\end{array}$ & $\begin{array}{c}\dot{Q}_{T M S, \max } \\
{[\mathrm{kJ} / \mathrm{s}]}\end{array}$ & $\begin{array}{c}\frac{\dot{Q}_{T M S, \max }}{m_{T M S}} \\
{[\mathrm{~kJ} /(\mathrm{s} \cdot \mathrm{kg})]}\end{array}$ & $\begin{array}{c}P_{T M S, \max } \\
\dot{Q}_{T M, \max } \\
{[-]}\end{array}$ \\
\hline Chapman et al. [29] & 176 & 272 & 505 & 2.86 & 0.54 \\
Rheaume et al. [27] & 250 & 30 & 209 & 0.83 & 0.14 \\
Rheaume et al. [18] & 78 & 17 & 210 & 2.70 & 0.08 \\
Lents et al. [30] & 152 & 51 & 221 & 1.45 & 0.23 \\
Jansen et al. [22] & 122.6 & - & 83 & 0.68 & - \\
\hline \hline
\end{tabular}

studies have optimized the component masses and power consumption by carefully analyzing the transient conditions between mission points. The general principle is that the TMS is not dimensioned to sustain steady-state operation at peak power. As long as the components' maximum admissible temperatures are not exceeded during the relatively short duration of take-off and initial climbing, excess heat is allowed to be rejected at higher altitudes when the air velocity is high, and the ambient temperature is low. It is assumed that a similar optimization can be done for the system modeled here.

It is worth noting that the systems in Table VIII are designed for battery systems. Due to the low operating temperatures of batteries $\left(<35-40{ }^{\circ} \mathrm{C}\right)$, the TMSs in Table VIII are expected to be heavier and consume more power per unit rejected heat load than will be the case with a PEMFC operating at a stack temperature of $85^{\circ} \mathrm{C}$.

For the optimistic 2035 scenario, it is speculated that further mass and power reduction can be achieved by also utilizing the aircraft's surface as a heat sink [31]. Table IX summarizes the parameter choices made for the three different scenarios.

TABLE IX

SIMULATION PARAMETERS, TMS

\begin{tabular}{lcccc}
\hline \hline \multirow{2}{*}{ Parameter } & \multirow{2}{*}{ Symbol } & \multicolumn{3}{c}{2035 scenario } \\
\cline { 3 - 5 } & & Conservative & Baseline & Optimistic \\
\hline$\dot{Q}_{T M S, \max } / m_{T M S}[\mathrm{~kJ} /(\mathrm{s} \cdot \mathrm{kg})]$ & $q m_{T M S}$ & 1.0 & 3.0 & 5.0 \\
$P_{T M S, \max } / \dot{Q}_{T M S, \max }[-]$ & $p q_{T M S}$ & 0.15 & 0.08 & 0.04 \\
\hline \hline
\end{tabular}

\section{G. Fuel Cell DC/DC Converter Sizing}

The authors have not been able to find published performance metrics on DC/DC converters operating at cryogenic 
temperatures. Warncke et al. [32] have published results on a conventionally cooled DC/DC converter for aircraft applications. They have achieved a power density of $8.3 \mathrm{~kW} / \mathrm{kg}$ for the power module alone, which is similar to what can be achieved for an optimized motor inverter with current conventional technology [33]. By operating the DC/DC converter at cryogenic temperatures, it is anticipated that power density and efficiency are improved in a fashion similar to the motor DC/AC inverter. However, it is still necessary to account for filters, etc., which add weight to the DC/DC converter. It is, therefore, stipulated that the cryogenic DC/DC converter will have a specific weight $50 \%$ higher than the cryogenic motor inverter. The efficiencies for the DC/DC converter are also set more conservatively than for the motor inverter. Table $\mathrm{X}$ summarizes these notional values.

TABLE X

SIMULATION PARAMETERS, DC/DC FUEL CELL CONVERTER

\begin{tabular}{lcccc}
\hline \hline \multirow{2}{*}{ Parameter } & \multirow{2}{*}{ Symbol } & \multicolumn{3}{c}{2035 scenario } \\
\cline { 3 - 5 } & & Conservative & Baseline & Optimistic \\
\hline PTW ratio [kW/kg] & $P T W_{D C D C}$ & 10 & 16 & 23 \\
Efficiency [\%] & $\eta_{D C D C}$ & 98.0 & 98.5 & 99.0 \\
\hline \hline
\end{tabular}

\section{H. PEM Fuel Cell Sizing}

Fig. 7 depicts the considered PEMFC model. In addition to the compressor and heat exchanger (FCHX) already described, the system comprises an air inlet diffuser, a humidifier, and balance-of-plant (BoP) components. The operating parameters, shown in green, are adopted from reference [1].

1) Required Fuel Cell Area: The electrical power output from a fuel cell is determined by the the average cell voltage and the cell current density multiplied with the total active cell area in the fuel cell, yielding

$$
P_{F C, e l}=U_{\text {cell }, \text { avg }} j_{\text {cell }} A_{F C, \text { eff }} .
$$

By rearranging eq. (13), the required total effective cell area can be determined from

$$
A_{F C, \text { eff }}=\frac{P_{F C, e l}}{U_{\text {cell }, \text { avg }} j_{\text {cell }}} .
$$

Here, $A_{F C \text {, eff }}$ must be dimensioned for the highest output power during the mission.

2) Fuel Cell Polarization Curves: The cell voltage is dependent on the current density in the fuel cell. This can be seen in the polarization plots in Fig. 8, extracted from Barbir [34].

The fuel cell's cathode can be fed with either air (airbreathing) or high-purity oxygen (air-independent) [35]. Fig. 8 shows how the cell voltage benefits from an air-independent operation.

In this study, only air-breathing configurations will be considered. For the conservative 2035 scenario, it is simply assumed that no improvements in the cell polarization curve as compared to Fig. 8 have been accomplished. The Linear Fit 1 curve is therefore employed in the conservative scenario.

Jiao et al. [36] have published a technology perspective for the performance of PEM fuel cells for automotive applications toward 2040. It is predicted that the PEMFC will operate at much higher current densities $\left(4 \mathrm{~A} / \mathrm{cm}^{2}\right)$ and higher cell voltages $(0.8-0.9 \mathrm{~V})$. These values represent a remarkable improvement in maximum cell power density $\left(5.3 \mathrm{~W} / \mathrm{cm}^{2}\right)$ compared to what is achievable with the polarization curve for an air-breathing PEMFC shown in Fig. $8\left(0.6 \mathrm{~W} / \mathrm{cm}^{2}\right)$.

Based on these promising projections, the polarization curve for the optimistic 2035 scenario is approximated by Linear Fit 3 in Fig. 8. This is a very notional estimate. With this model, the maximum cell power density is still below 1 $\mathrm{W} / \mathrm{cm}^{2}$.

The baseline polarization curve is set to coincide with the air-independent curve in Fig.8, which lies about halfway between the two extremes.

As can be seen from Fig. 8 the linear approximations closely match the actual polarization curves in the range $0.1 \mathrm{~A} \leq j_{\text {cell }} \leq 1.4 \mathrm{~A} / \mathrm{cm}^{2}$. In practice, $j_{\text {cell }}$ will never exceed $1.4 \mathrm{~A} / \mathrm{cm}^{2}$, but an error is introduced for current densities below $0.1 \mathrm{~A} / \mathrm{cm}^{2}$. This is deemed acceptable since this mode of operation only occurs for a very small part of the mission. Furthermore, it has no impact on the sizing of the components.

Table XI lists the coefficients $a_{p o l}$ and $b_{p o l}$ used for the three linear approximation curves Linear Fit 1-3, to be used in eq. (15).

TABLE XI

COEFFICIENTS FOR APPROXIMATION OF POLARIZATION VOLTAGE

\begin{tabular}{lcc}
\hline \hline Linear approximation & $a_{p o l}\left[\mathrm{Vcm}^{2} / \mathrm{A}\right]$ & $b_{p o l}[\mathrm{~V}]$ \\
\hline Linear Fit 1 (conservative) & -0.2957 & 0.8539 \\
Linear Fit 2 (baseline) & -0.2320 & 0.8956 \\
Linear Fit 3 (optimistic) & -0.1875 & 0.9500 \\
\hline \hline
\end{tabular}

The appropriate set of coefficients in Table XI can now be used to establish an approximate average cell voltage, yielding

$$
U_{\text {cell }, a v g} \approx a_{\text {pol }} \cdot j_{\text {cell }}+b_{\text {pol }} .
$$

3) Fuel Cell Efficiency: The fuel cell efficiency is derived from the average cell voltage. Throughout this study, the higher heating value (HHV) of hydrogen is used. When small parasitic phenomena are ignored, the fuel cell efficiency simply becomes [34]

$$
\eta_{F C, e l, H H V}=\frac{U_{c e l l, a v g}}{1.481} .
$$

4) Stoichiometric Ratios: The mass flow of hydrogen fed into the anode is always larger than the mass flow that goes into the fuel cell reaction. The ratio between these mass flows is given by the stoichiometric ratio, which is always greater than one. This means that the anode output will contain unutilized hydrogen. This hydrogen can be rejected as exhaust, but this leads to poor fuel efficiency. The alternative is either to recycle the excess hydrogen from the anode output by feeding it back into the main fuel line or to employ deadend anode operation [37]. The former approach is assumed here, as shown in Fig. 7.

The stoichiometric ratio $\lambda_{O_{2}}$ on the cathode side is also greater than one. The stoichometric ratios used in this paper are adopted from Schröder et al. [1]. There, a net stoichiometric ratio of $\lambda_{H_{2}, \text { net }}=1.05$ is achieved through hydrogen recirculation. Also, $\lambda_{O_{2}}=1.8$ is assumed. 


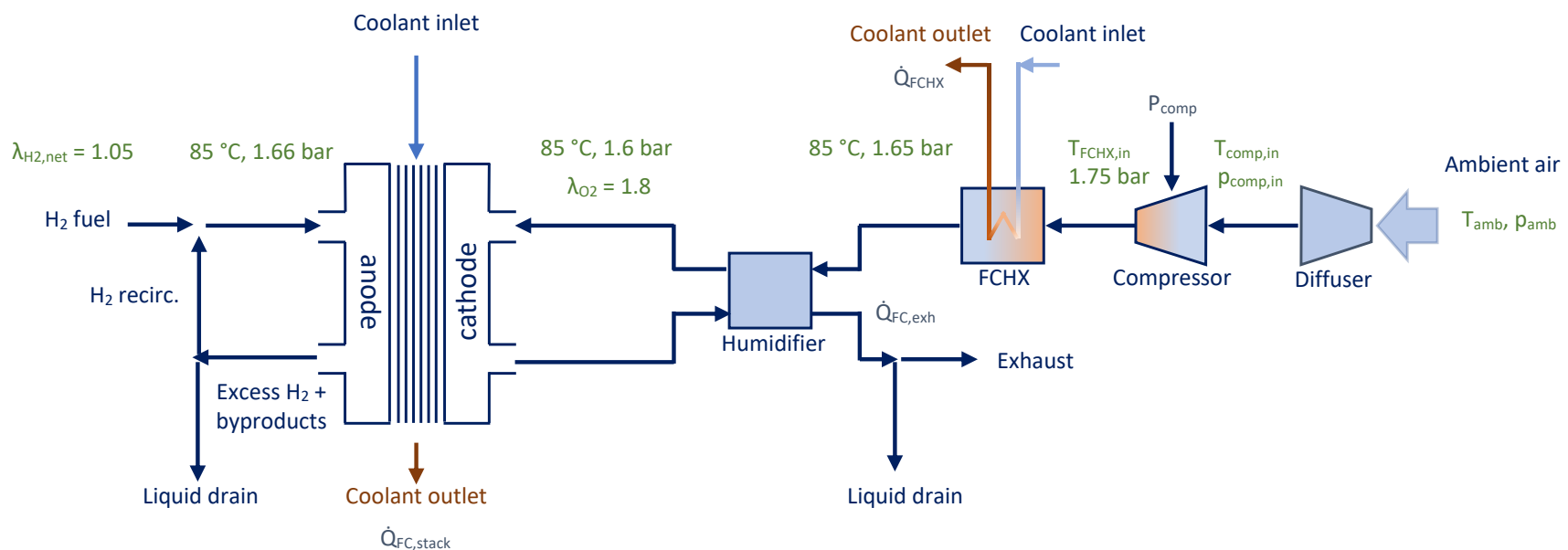

Fig. 7. Fuel cell and auxiliary components. Operating parameters (in green) are adopted from Schröder et al. [1]

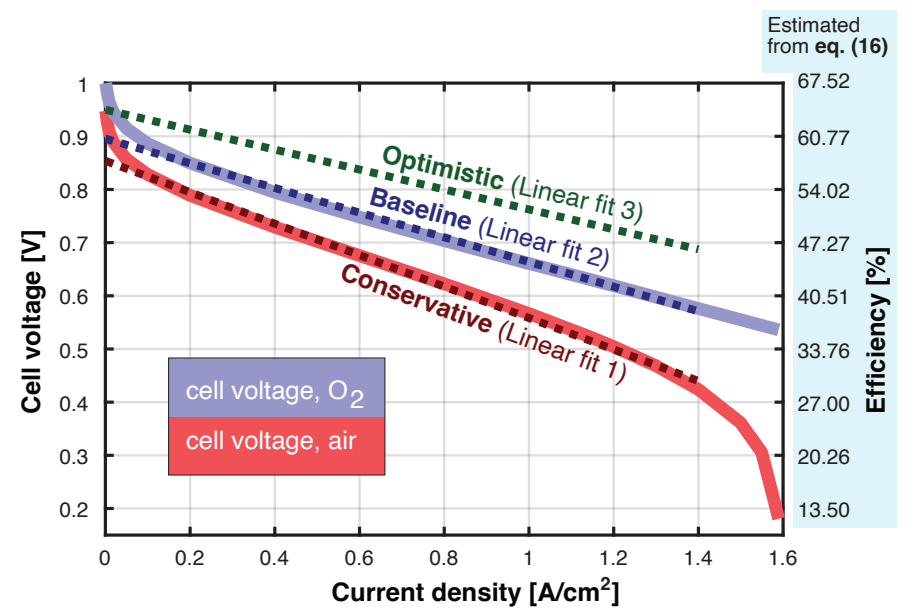

Fig. 8. Fuel cell polarization curves for air and oxygen, adopted from Barbir [34]. Linear Fit 1-3 represent the approximations used in the conservative, baseline, and optimistic scenarios, respectively. Eq. (16) is used to estimate the FC's efficiency for the y-axis on the right-hand side.

5) Mass Flow: The required mass flow of hydrogen is now given by

$$
\dot{m}_{H_{2}, \text { in }}=\frac{\lambda_{H_{2}, n e t} P_{F C, e l}}{\eta_{\text {cell }} \Delta h_{H_{2}, H H V}} .
$$

On the cathode side, the air mass flow is given by [35]

$$
\dot{m}_{a i r, i n}=\frac{j_{c e l l} A_{F C, \text { eff }}}{4 F \cdot x_{\mathrm{O}_{2}}} \lambda_{\mathrm{O}_{2}} M_{\text {air }} .
$$

6) Chemical Power Delivered to the PEMFC: The chemical power (HHV) delivered to the fuel cell is calculated

$$
P_{H_{2}, H H V}=\dot{m}_{H_{2}, i n} \Delta h_{H_{2}, H H V} .
$$

7) Compressor Power: The ambient temperature and pressure are given by eqs. (1) and (2). The required cathode compressor power $\left(P_{\text {comp }}\right)$ can now be established by first calculating the specific enthalpy change over the compressor and then scaling for cathode air mass flow and adjusting for compressor efficiencies. Eqs. (20) through (24) have been adopted from Schröder et al. [1], [38], [39]. For simplicity, the input filter has been omitted from the model.

Compressor inlet temperature can be formulated

$$
T_{c o m p, i n}=T_{a m b}+\frac{\left(\sqrt{\gamma_{a i r} R_{s p, a i r} T_{a m b}} \cdot M a\right)^{2}}{2 c_{p, a i r}} .
$$

Maximum achievable static pressure at the compressor inlet is given by

$$
p_{c o m p, i n, s t a t}=p_{a m b}\left(\frac{T_{c o m p, i n}}{T_{a m b}}\right)^{\frac{\gamma_{a i r}}{\gamma_{a i r}-1}} .
$$

Pressure at the compressor inlet are found from

$$
p_{c o m p, i n}=\eta_{p r}\left(p_{c o m p, i n, s t a t}-p_{a m b}\right)+p_{a m b} .
$$

Change in specific enthalphy is expressed as

$\Delta h_{\text {comp }}=\frac{1}{\eta_{\text {comp }, s}} c_{p, a i r} T_{\text {comp }, i n}\left[\left(\frac{p_{F C H X, i n}}{p_{c o m p, i n}}\right)^{\frac{R_{s p, a i r}}{c_{p, a i r}}}-1\right]$.

Finally, the required compressor power is

$$
P_{\text {comp }}=\frac{\Delta h_{c o m p} \dot{m}_{a i r, i n}}{\eta_{c o m p, m} \eta_{c o m p, e l} \eta_{c o m p, p c}} .
$$

8) Heat Rejected to FCHX: The temperature at the compressor's outlet can be approximated by

$$
T_{F C H X, i n} \approx T_{c o m p, i n}+\Delta h_{c o m p} .
$$

Setting $\Delta T_{\text {comp }} \approx \Delta h$ (in $\left.\mathrm{kJ} / \mathrm{kg}\right)$ is a good approximation in the 200-550 $\mathrm{K}$ temperature range.

The heat rejected from the fuel cell's heat exchanger is estimated as

$$
\dot{Q}_{F C H X}=c_{p, a i r} \dot{m}_{a i r, i n}\left(T_{F C H X, i n}-T_{F C H X, o u t}\right) .
$$

9) Heat Rejected From the Fuel Cell Stack: The HHV chemical power that contribute to the reaction in the fuel cell is given by

$$
P_{H_{2}, H H V, e f f}=P_{H_{2}, H H V} \frac{1}{\lambda_{H_{2}, n e t}} .
$$

The total thermal loss in the PMFC is found from

$$
\dot{Q}_{F C, \text { stack }}+\dot{Q}_{F C, e x h}=P_{H_{2}, H H V, e f f}-P_{F C, e l} \text {. }
$$


Here, the thermal loss has been split into two terms. The first term, $\dot{Q}_{F C, \text { stack }}$, represents the heat load that must be removed from the stack by the TMS. The second term, $\dot{Q}_{F C, \text { exh }}$ represents the heat load rejected at the cathode exhaust. The fraction of the total thermal losses rejected to the TMS is approximated by $\lambda_{F C, T M S}$. This fraction is coarsely estimated to be 0.95 [40]. Each of the terms on the left side of eq. (28) can thus be written as

$$
\begin{gathered}
\dot{Q}_{F C, \text { stack }}=\lambda_{F C, T M S}\left(P_{H_{2}, H H V, \text { eff }}-P_{F C, e l}\right), \\
\dot{Q}_{F C, \text { exh }}=\left(1-\lambda_{F C, T M S}\right)\left(P_{H_{2}, H H V, \text { eff }}-P_{F C, e l}\right) .
\end{gathered}
$$

10) Mass Estimates: The PEMFC mass estimate is based on the weight of the fuel cell stack, the compressor, and the humidifier. This is in accordance with the approach of Schröder et al. [1]. Additionally, a mass overhead is added to account for the remaining balance of plant (BoP) components, structural materials, etc.

The fuel cell mass is calculated from the total effective cell area, yielding

$$
m_{\text {stack }}=\rho_{A, F C, \text { eff }} \cdot A_{F C, \text { eff }} .
$$

Correspondingly, the masses of the compressor and humidifier are calculated from the power densities of the respective components, yielding

$$
\begin{aligned}
& m_{\text {comp }}=\rho_{\text {comp }} \cdot P_{\text {comp }}, \\
& m_{\text {hum }}=\rho_{\text {hum }} \cdot \dot{m}_{\text {air }, \text { in }} .
\end{aligned}
$$

Finally, the overhead mass for BoP, etc., is taken as a fraction of the sum of the masses from eqs. (31), (32) and (33), yielding

$$
m_{B o P}=\lambda_{B o P}\left(m_{\text {stack }}+m_{\text {comp }}+m_{\text {hum }}\right) .
$$

11) Choice of Parameters for PEMFC Simulation Scenarios: The simulation parameters for the PEMFC are given in Table XII.

The mass parameters for the conservative scenario have been set in accordance with Schröder et al. [1]. The exception is the BoP overhead factor (last row), which has been set subjectively.

The optimistic compressor mass density estimate is set to $0.3 \mathrm{~kg} / \mathrm{kW}$. It is here assumed that a superconducting machine is employed to drive the compressor. This will necessitate hydrogen cooling, which would lead to a small increase in hydrogen temperatures. This is neglected here due to the low power rating of the compressor motor relative to the propulsion motors. It is also assumed that the humidifier mass density can be reduced moderately, while the BoP overhead factors are kept unchanged.

Jiao et al. [36] predict that in 2040 the volumetric power densities of the stack can reach values approaching $9 \mathrm{~kW} / \mathrm{l}$, compared to today's $5 \mathrm{~kW} / \mathrm{l}$ (state-of-the-art). For the optimistic scenario in Table XII it is assumed that the fuel stack mass density can be reduced to $1 / 3$ of the conservative estimate. This choice must be seen in conjunction with the choice of a very low maximum cell power density set in Section V-H2, as compared to the predictions in reference [36].

An average of the conservative and optimistic parameters is used for the baseline case. Table XII summarizes the parameter choices.

TABLE XII

SIMULATION PARAMETERS, PEMFC

\begin{tabular}{lcccc}
\hline \hline \multirow{2}{*}{ Parameter } & \multirow{2}{*}{ Symbol } & \multicolumn{3}{c}{2035 scenario } \\
\cline { 3 - 5 } & & Conservative & Baseline & Optimistic \\
\hline Polarization curve coeffs. $[-]$ & $a_{\text {pol }}, b_{\text {pol }}$ & Lin. fit 1 & Lin. fit 2 & Lin. fit 3 \\
Fuel stack mass density $\left[\mathrm{kg} / \mathrm{m}^{2}\right]$ & $\rho_{A, F C, \text { eff }}$ & 2.5 & 1.65 & 0.8 \\
Compressor mass density $[\mathrm{kg} / \mathrm{kW}]$ & $\rho_{\text {comp }}$ & 0.53 & 0.4 & 0.3 \\
Humidifier mass density $[\mathrm{kg} /(\mathrm{kg} / \mathrm{s})]$ & $\rho_{\text {hum }}$ & 82.35 & 70 & 60 \\
Fuel cell BoP overhead factor $[-]$ & $\lambda_{\text {BoP }}$ & 0.2 & 0.2 & 0.2 \\
\hline \hline
\end{tabular}

\section{PTW and End-to-End Efficiency for the System}

The PTW of the total system is defined as the ratio of maximum propeller power $(4.1 \mathrm{MW})$ to the total system weight, where

$$
P T W_{t o t}=\frac{P_{p r o p, \max }}{m_{t o t}} .
$$

Moreover, the average end-to-end efficiency is defined as the ratio of total energy drawn from the fuel tank to the total energy delivered to the propeller over the entire mission, yielding

$$
\eta_{\text {tot }, \text { avg }}=\frac{\int_{0}^{e . o . m .} P_{H_{2}, H H V}(t) d t}{\int_{0}^{e . o . m .} P_{\text {prop }}(t) d t} .
$$

Here, e.o.m. is the time at the end of mission.

\section{ANALYSIS AND MAIN RESULTS}

This section describes how all the obtained results were obtained before presenting the main results and analyzing their implications.

\section{A. Simulation Model}

The simulation model has been implemented in the MATLAB numerical environment. In the following subsections, the model implementation will be described from the bottom and up, starting with the Power Model which calculates the power and heat load balance in the system at any given operating point. Next comes the Mission Iteration module, which calls on the Power Model at each timestep during the mission profile. Lastly, the sequence of the Simulation Steps is explained.

1) Power Model: The flowchart for the Power Model is depicted in Fig. 9. It takes the propeller power at any given time instance as an input variable. It also takes either a specified maximum $\mathrm{FC}$ current density, $j_{\text {cell, max }}$ or a specified total effective fuel cell area, $A_{F C, \text { eff } f}$ as an input parameter. The model formulation is slightly different for the two cases, hence the two formulations Formulation 1 and Formulation 2.

As mentioned at the beginning of Section $\mathrm{V}$ the power rating and heat loads of the components are calculated in the upstream direction. This is trivial for the gear, the SCM, the DC/AC inverter, and the HTS cables. These values are calculated directly, as can be seen in Fig. 9.

The TMS and the FC compressor power can not be determined directly because their power requirements are 


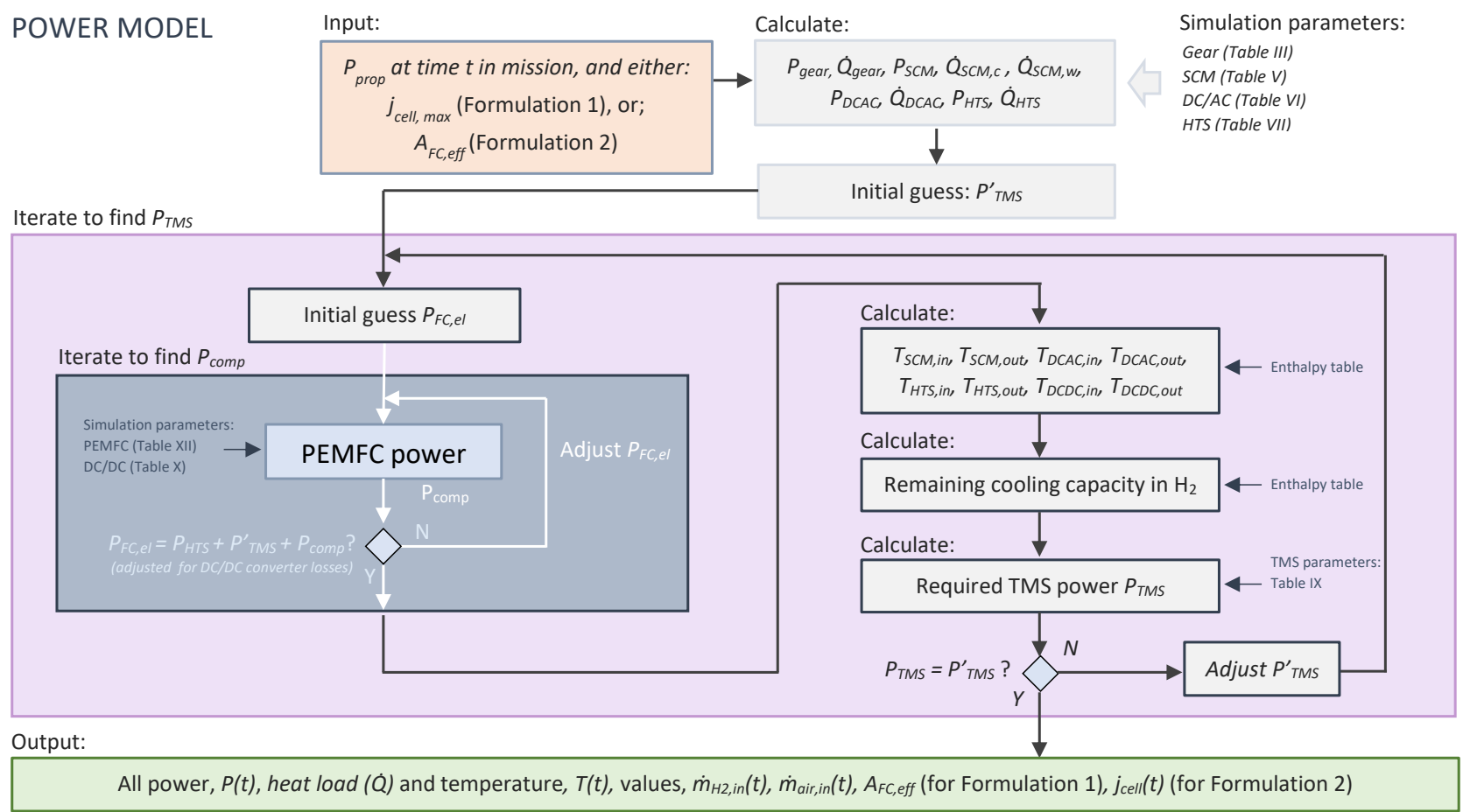

Fig. 9. Flowchart of Power Model.

dependent on the operation point of the PEMFC and vice versa. In the Power Model this has been solved by introducing two iteration loops. The outer loop starts with an initial guess, $P_{T M S}^{\prime}$, and uses this to calculate the actual TMS power demand, $P_{T M S} . P_{T M S}^{\prime}$ is then adjusted until the two values come out equal within a specified tolerance $( \pm 100 \mathrm{~W})$.

The inner loop does the same for the compressor power, $P_{\text {comp }}$. The PEMFC output power, $P_{F C, e l}$, is adjusted until its power balances with the load (within $\pm 100 \mathrm{~W}$ ).

Since the DC/DC converter lies between these components, its efficiency is accounted for in these calculations.

2) Mission Iteration: The Power Model must be run for each timestep over the full mission. The Mission Iteration sequence depicted in Fig. 10 calls on the Power Model to do this. Mission Iteration outputs all power, heat load, mass flow and temperature values at each time instance. The maximum power and mass flow values required to size the components are also collected in the sequence.

3) Simulation Steps: Fig. 11 outlines the overall sequence followed for each simulation case.

The first step is to specify the input parameters to the simulation. See Table XIII for further details.

The second step is to determine what $j_{\text {cell,max }}$ value yields the lowest total system mass, $m_{t o t}$. In this step, all component masses are calculated for a range of $j_{c e l l, \max }$ input values. The maximum PEMFC power, $P_{F C \text {,el }}$, occurs at $t=60 \mathrm{~s}$. This operation is used to determine the required effective FC

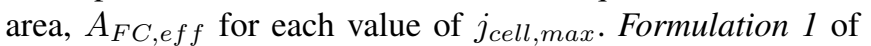
the Mission Model is used for this purpose. Once $A_{F C, \text { eff }}$ has been determined, each mission point is evaluated by calling Mission Iteration. The breakdown of the component masses are stored for each value of $j_{\text {cell,max }}$.
The third step is to evaluate the resulting component masses as a function of $j_{c e l l, \max }$ and identify the value of $A_{F C, \text { eff }}$ that yields the minimum system mass. The corresponding $A_{F C \text {, eff }}$ is then used as an input to step four.

In the fourth and last step, Mission Iteration is run with the FC cell area, $A_{F C, e f f}$, that yielded minimum mass in the previous step to produce all required output values for further evaluation.

\section{B. Simulation Cases}

Table XIII lists all the simulation cases that have been analyzed. For each of the main scenarios, Baseline (B), Optimistic $(O)$ and Conservative $(C)$, four different constellations are simulated. The difference lies in whether the system comprises a gearbox or not, and whether the hydrogen enters the cooling circuit as saturated vapor at $22.164 \mathrm{~K}$ (gaseous cooling) or fully liquid at $20 \mathrm{~K}$ (two-phase cooling).

A sensitivity study, S1, has also been performed. The study is centered around the baseline values. Each of the SCM parameters are varied individually, while all other parameters are kept at their baseline values.

Simulation cases $B 1$ and $B 2$ (highlighted in blue) are used as comprehensive case studies in Section VI-C below. The same approach is subsequently applied to all the other scenarios, but then only the main results are reported.

\section{Case Study, Simulation Cases B1 and B2}

The simulation steps described in the flowchart in Fig. 11 have been followed. After the input parameters have been defined, the value for $j_{\text {cell, } \max }$ that minimizes the total system mass can be found. Fig. 12 shows the resulting total system mass for simulation case $B l$ for $j_{\text {cell,max }}$ values 


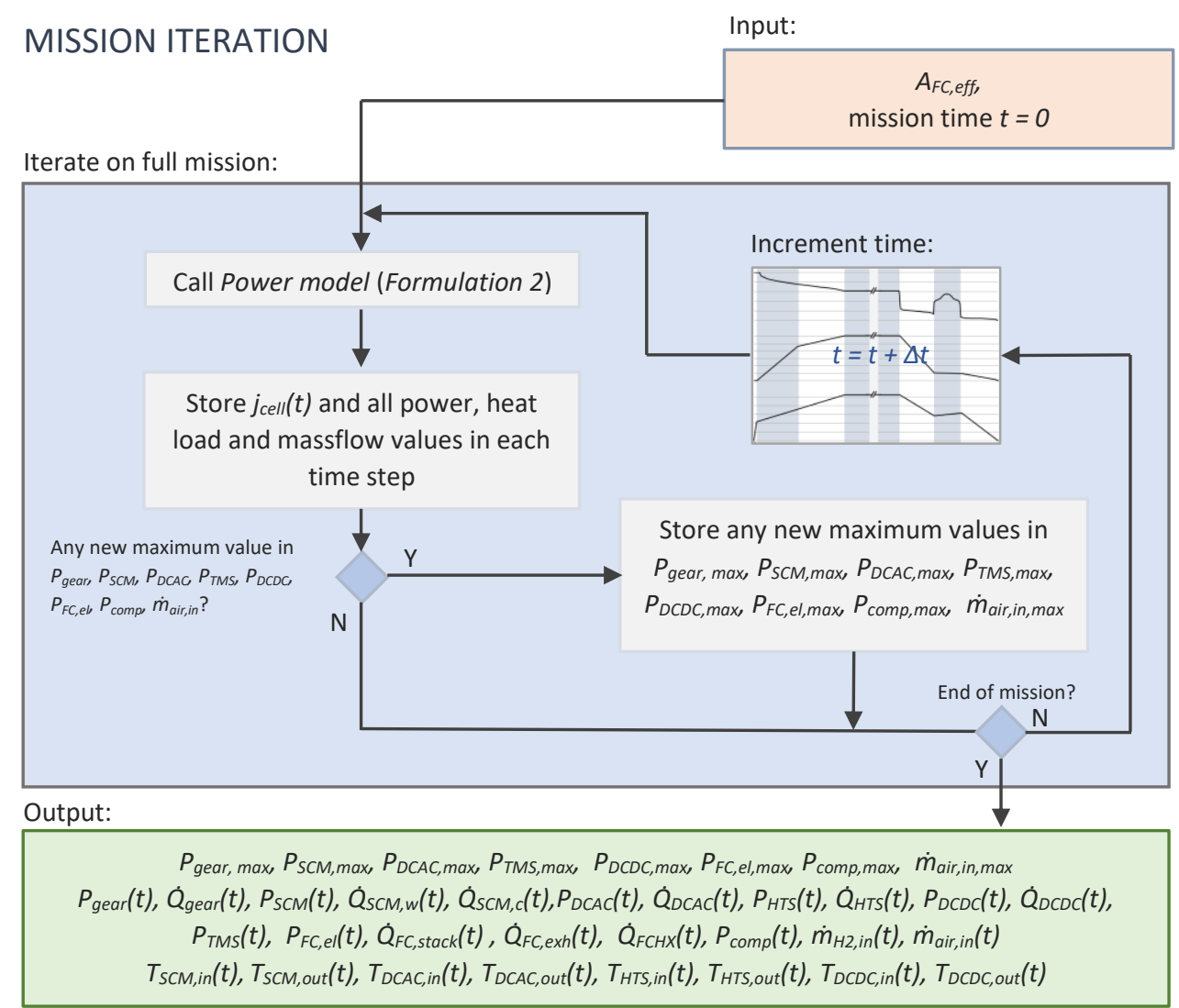

Fig. 10. Flowchart of Mission Iteration.

TABLE XIII

SIMULATION MATRIX

\begin{tabular}{|c|c|c|c|c|c|c|c|c|}
\hline Study & Case No. & 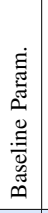 & 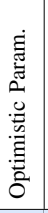 & 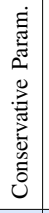 & 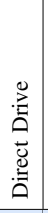 & లँّ & $\begin{array}{l}\stackrel{00}{\Xi} \\
0 \\
0 \\
0 \\
0 \\
0 \\
0 \\
0 \\
0\end{array}$ & 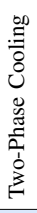 \\
\hline \multirow{3}{*}{$\begin{array}{l}\text { Baseline } \\
\text { Scenario }\end{array}$} & $\begin{array}{l}\text { B1 } \\
\text { B2 }\end{array}$ & $\begin{array}{l}\mathrm{X} \\
\mathrm{X}\end{array}$ & & & $\begin{array}{l}\mathrm{X} \\
\mathrm{X}\end{array}$ & & $\mathrm{X}$ & $\mathrm{X}$ \\
\hline & B3 & $\mathrm{X}$ & & & & $\mathrm{X}$ & $\mathrm{X}$ & \\
\hline & B4 & $\mathrm{X}$ & & & & $\mathrm{X}$ & & $\mathrm{X}$ \\
\hline \multirow{4}{*}{$\begin{array}{l}\text { Optimistic } \\
\text { Scenario }\end{array}$} & O1 & & $\mathrm{X}$ & & $\mathrm{X}$ & & $\mathrm{X}$ & \\
\hline & $\mathrm{O} 2$ & & $\mathrm{X}$ & & $\mathrm{X}$ & & & $\mathrm{X}$ \\
\hline & $\mathrm{O} 3$ & & $\mathrm{X}$ & & & $\mathrm{X}$ & $\mathrm{X}$ & \\
\hline & O4 & & $\mathrm{X}$ & & & $\mathrm{X}$ & & $\mathrm{X}$ \\
\hline \multirow{4}{*}{$\begin{array}{l}\text { Conservative } \\
\text { Scenario }\end{array}$} & $\mathrm{C} 1$ & & & $\mathrm{X}$ & $\mathrm{X}$ & & $\mathrm{X}$ & \\
\hline & C2 & & & $\mathrm{X}$ & $\mathrm{X}$ & & & $\mathrm{X}$ \\
\hline & C3 & & & $\mathrm{X}$ & & $\mathrm{X}$ & $\mathrm{X}$ & \\
\hline & $\mathrm{C} 4$ & & & $\mathrm{X}$ & & $\mathrm{X}$ & & $\mathrm{X}$ \\
\hline $\begin{array}{l}\text { Sensitivity Study, } \\
\text { SCM }\end{array}$ & S1 & $X$ & & & $\mathrm{X}$ & $\mathrm{X}$ & $\mathrm{X}$ & \\
\hline
\end{tabular}

ranging from $0.3-1.1 \mathrm{~A} / \mathrm{cm}^{2}$. A minimum total system mass of $m_{t o t}=5331 \mathrm{~kg}$ is achieved for $j_{\text {cell, } \text { max }}=0.8 \mathrm{~A} / \mathrm{cm}^{2}$. For this point, the total effective FC area is $A_{F C \text {, eff }}=894 \mathrm{~m}^{2}$.

When two-phase cooling is employed instead (case B2) a very similar result is obtained. Here, the minimum total system mass of $5316 \mathrm{~kg}$ is achieved for $j_{\text {cell, } \max }=0.8$ $\mathrm{A} / \mathrm{cm}^{2}$.
Fig. 13 plots the instantaneous values for the output power $\left(P_{\text {prop }}\right)$, fuel cell current density $\left(j_{\text {cell }}\right)$, compressor power $\left(P_{c o m p}\right)$ and total end-to-end efficiency $\left(\eta_{t o t}\right)$ over the entire mission. The results are from simulation case $\mathrm{B} 1$. The results from simulation case B2 are practically identical, and have been omitted.

In Fig. 13b, the maximum current density occurs at $t=60$ $\mathrm{s}$ with $j_{\text {cell, } \max }=0.8 \mathrm{~A} / \mathrm{cm}^{2}$. The compressor power in Fig. $13 \mathrm{c}$ peaks at $550 \mathrm{~kW}$. This happens at $t=480 \mathrm{~s}$ (top of initial climb). This is an important observation since it demonstrates how the sizing of the compressor is not only dependent on the system's power, but also on the ambient air pressure. Finally, it is observed in Fig. 13d that the total end-to-end system efficiency depends on both propulsive power and altitude. The average end-to-end efficiency, $\eta_{\text {tot, avg }}$, calculated from eq. (36) is $38.54 \%$. When two-phase cooling is employed (case B2), the average end-to-end efficiency is practically identical $(38.56 \%)$.

Fig. 14 gives a detailed account of the power and heat flow in the system at maximum power and cruise power in case B1. The PEMFC operates at a higher efficiency at cruise power compared to maximum power, but this has little actual impact on the end-to-end efficiency due to the higher compressor power at cruise altitude.

The power and heat flow in case $B 2$ is very similar to case $B 1$ (Fig. 14). The only notable difference is that a larger fraction of the heat load from the FC stack is rejected to the hydrogen in case $B 2$. This is due to the fact that the total 


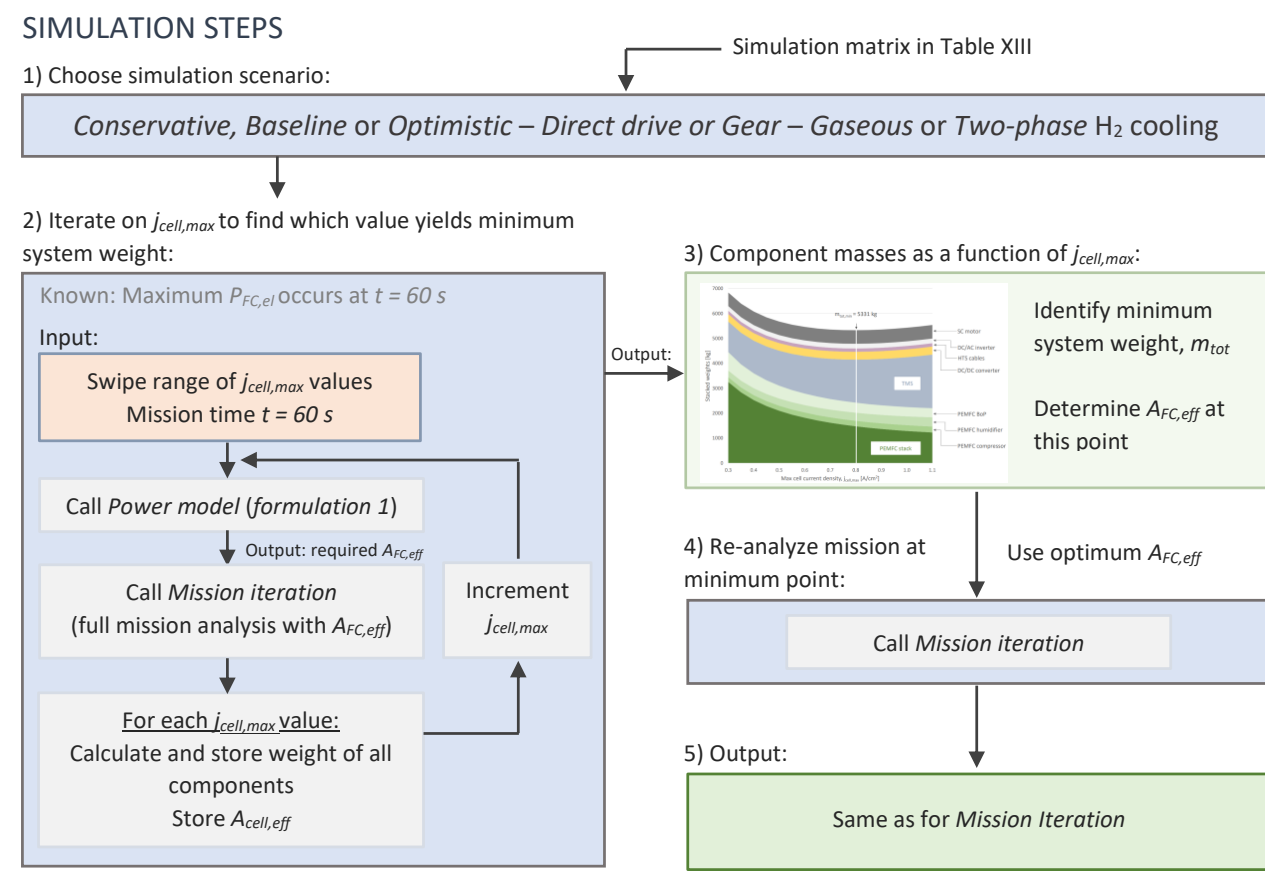

Fig. 11. Flowchart of Simulation Steps

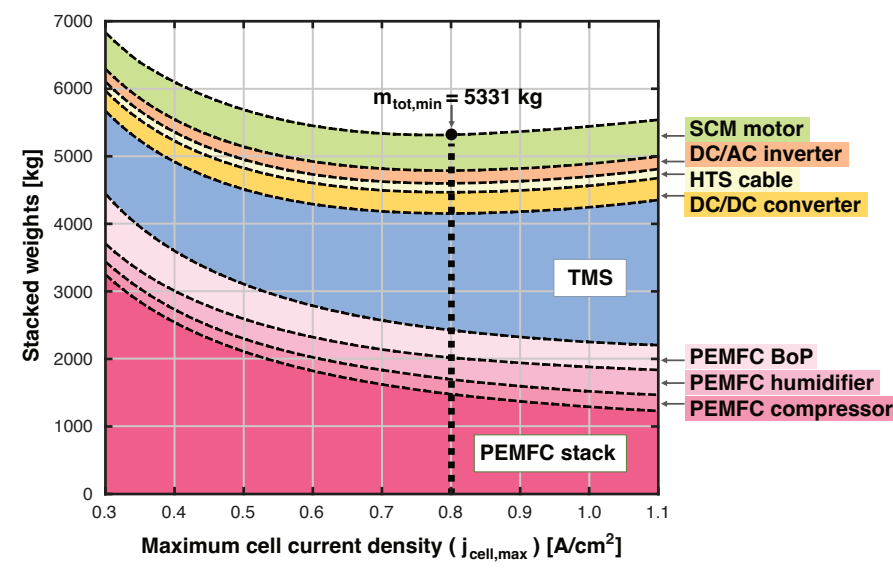

Fig. 12. Case B1: System mass vs. maximum PEMFC current density $j_{\text {cell, } \max }$. Minimum mass at $j_{\text {cell, } \max }=0.8 \mathrm{~A} / \mathrm{cm}^{2}$

cooling capacity of the hydrogen is larger when two-phase cooling is employed. In case $B 2$ the normalized heat load from the FC stack rejected to hydrogen is $2.2 \%$ and $2.1 \%$ at maximum and cruise power, respectively, compared to 1.9 $\%$ and $1.8 \%$ in case $B 1$.

In the results presented thus far, the difference between case $B 1$ and $B 2$ has been negligible or very small. This is not the case for the hydrogen temperatures, where the initial state of the hydrogen in the cryogenic cooling circuit makes a large difference.

Fig. 15-(a) shows how the temperature over the cryogenic components vary over the mission in case $B l$ when the hydrogen enters the cooling circuit as saturated vapor $(T=$ 22.164 K). Fig. 15-(b) shows the same profile for case $B 2$ when the hydrogen enters the cooling circuit as a liquid at $20 \mathrm{~K}$.

It is interesting to observe that the maximum temperatures
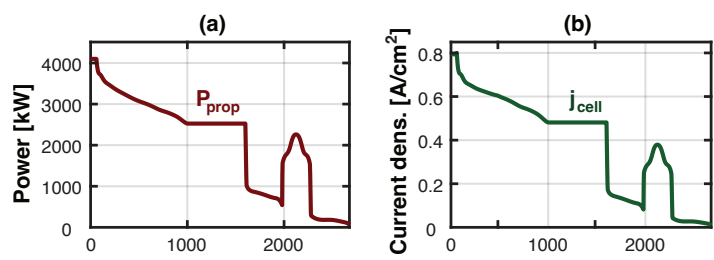

(c)
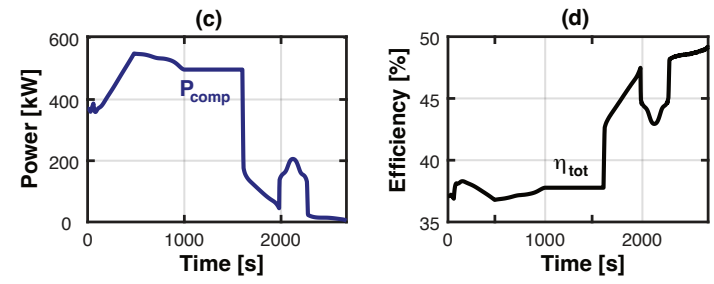

Fig. 13. Case B1 over the entire mission, where the results from case B2 are practically identical. (a): Propeller power $\left(P_{\text {prop }}\right)$. (b): Fuel cell current density $\left(j_{\text {cell }}\right)$. (c): Compressor power $\left(P_{\text {comp }}\right)$. (d): Total system efficiency $\left(\eta_{\text {tot }}\right)$.

occur at the end of the mission when the system operates at low power. At full power, the hydrogen temperatures are near their minimum values.

The hydrogen temperature over the superconducting components have maximum values $T_{S C M, \text { max }}=54.0 \mathrm{~K}$ and $T_{H T S, \max }=57.3 \mathrm{~K}$. With this cooling arrangement it is therefore not possible to utilize $\mathrm{MgB}_{2}$ conductors in the SCM since the limiting temperature of $25 \mathrm{~K}$ is exceeded (cf. Table I). By using REBCO instead, it is possible to stay within the defined maximum allowable operating temperatures of $60 \mathrm{~K}$ and $77 \mathrm{~K}$ for the SCM and HTS cables, respectively.

The maximum hydrogen temperature in the DC/AC inverter, $T_{D C A C, \max }$, is $108.8 \mathrm{~K}$. This is within the $110 \mathrm{~K}$ temperature limit defined in Table I. The temperature in the DC/DC converter experiences a maximum temperature $T_{D C D C, \max }=204.9 \mathrm{~K}$ and thus exceeds the $110 \mathrm{~K}$ limit set 


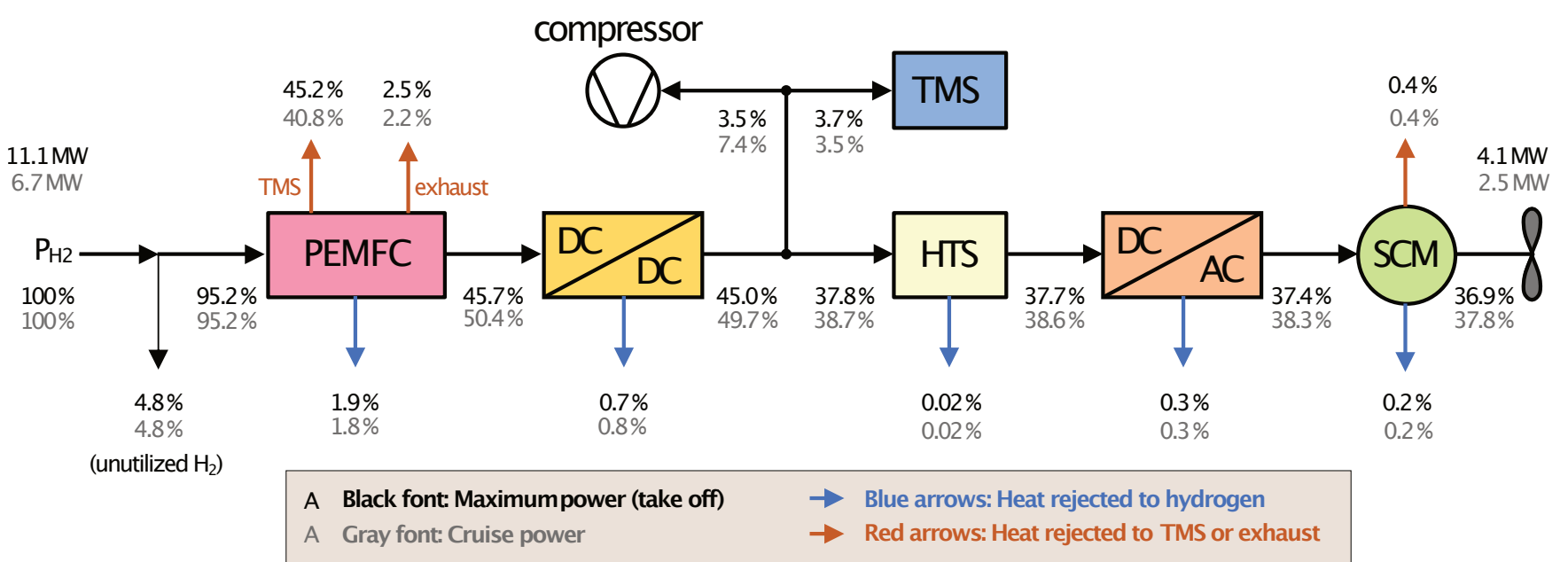

Fig. 14. Case B1: Detailed power and heat flow at maximum power and cruise power. All values are normalized to $P_{H_{2}}$.

(a)

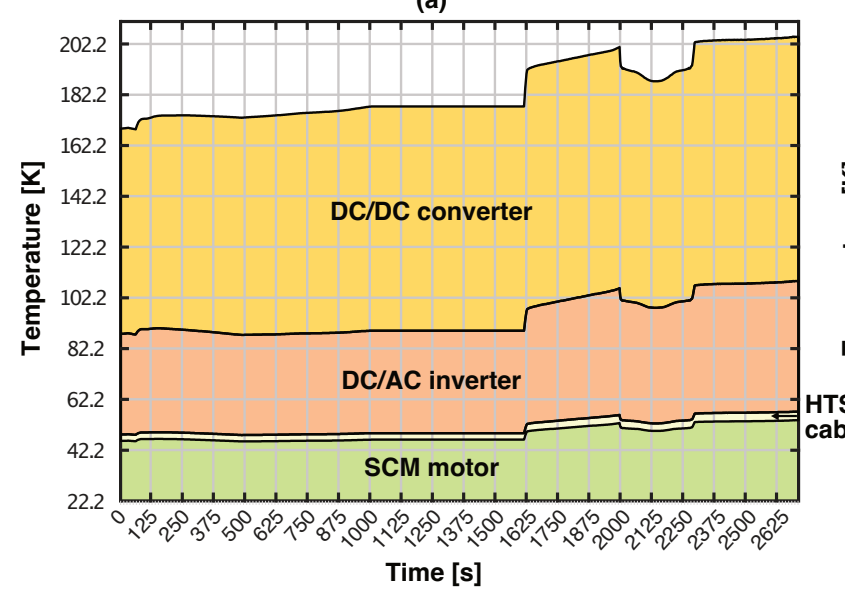

(b)

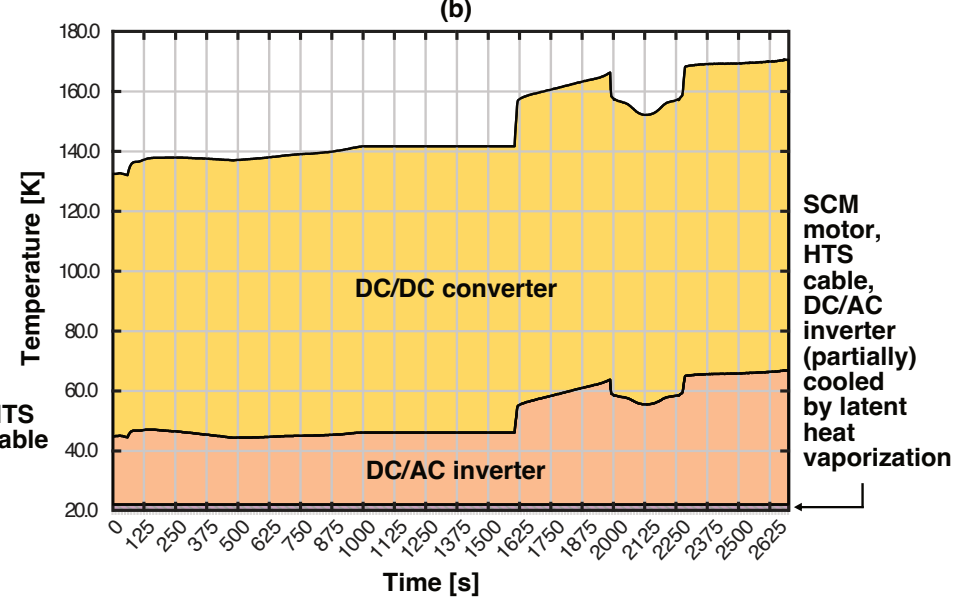

Fig. 15. Hydrogen temperature profile over mission. (a): Gaseous $H_{2}$ cooling (case $B 1$ ). (b): Two-phase $H_{2}$ cooling (case $B 2$ ).

for cold power electronics.

In Fig. 15-(b), hydrogen enters the cooling circuit fully liquid at $20 \mathrm{~K}$. Due to the high latent heat of vaporization $(438 \mathrm{~kJ} / \mathrm{kg})$, the hydrogen absorbs a substantial amount of heat during the phase-change at $T=22.164 \mathrm{~K}$. Both the SCM and the HTS cables operate at saturation temperature $(22.164 \mathrm{~K})$ through the entire mission which means that either $\mathrm{MgB}_{2}$ or REBCO are possible options for the SCM in this arrangement. At $T_{D C A C, \max }=66.9 \mathrm{~K}$ the $\mathrm{DC} / \mathrm{AC}$ inverter is well within its $110 \mathrm{~K}$ limit, whereas the DC/DC converter falls outside with $T_{D C D C, \max }=170.6 \mathrm{~K}$.

\section{Compilation of Simulation Results From Cases B, $O$ and C}

1) Performance Metrics: Tables XIV, XV and XVI summarizes the simulation results from the Baseline, Optimistic and Conservative scenarios.

When evaluated against the performance targets set for the study (Table I) all the Conservative scenarios fail to meet the majority of the defined targets. The situation is more promising for the Baseline and Optimistic scenarios. The matrix in Table XVII summarizes the targets met for each case.
TABLE XIV

PERFormanCE METRICS, BASELINE SCENARIO (B), $j_{\text {cell }, \text { max }}=0.8$.

\begin{tabular}{|c|c|c|c|c|c|}
\hline \multirow[b]{3}{*}{ Metric } & \multirow[b]{3}{*}{ Unit } & \multicolumn{2}{|c|}{$\begin{array}{c}\text { Direct drive } \\
\left(\mathrm{n}_{\mathrm{SCM}}=1200 \mathrm{rpm}\right)\end{array}$} & \multicolumn{2}{|c|}{$\begin{array}{c}\text { With gear } \\
\left(\mathrm{n}_{\mathrm{SCM}}=3500 \mathrm{rpm}\right)\end{array}$} \\
\hline & & B1 & B2 & B3 & B4 \\
\hline & & $\begin{array}{l}\text { Gaseous } \\
\text { cooling }\end{array}$ & $\begin{array}{c}\text { Two-phase } \\
\text { cooling }\end{array}$ & $\begin{array}{c}\text { Gaseous } \\
\text { cooling }\end{array}$ & $\begin{array}{c}\text { Two-phase } \\
\text { cooling }\end{array}$ \\
\hline$m_{t o t}$ & $\mathrm{~kg}$ & 5331 & 5316 & 5178 & 5162 \\
\hline$P T W_{t o t}$ & $\mathrm{~kW} / \mathrm{kg}$ & 0.77 & 0.77 & 0.79 & 0.79 \\
\hline$\eta_{t o t, a v g}$ & $\%$ & 38.54 & 38.56 & 38.12 & 38.15 \\
\hline$T_{S C M, \max }$ & $\mathrm{K}$ & 54.0 & 22.2 & 53.9 & 22.2 \\
\hline$T_{H T S, \max }$ & K & 57.3 & 22.2 & 57.3 & 22.2 \\
\hline$T_{D C A C, \max }$ & K & 108.8 & 66.9 & 108.7 & 66.8 \\
\hline$T_{D C D C, \max }$ & $\mathrm{K}$ & 204.9 & 170.6 & 204.9 & 170.5 \\
\hline
\end{tabular}

Only cases $O 2$ and $O 4$ satisfy all the defined target limits. These are the Optimistic cases where two-phase hydrogen cooling is employed. These are also the only two cases where the maximum hydrogen temperature in the DC/DC converter, $T_{D C D C, \max }$, does not exceed the $110 \mathrm{~K}$ limit during the mission.

2) Distribution of Component Masses: Fig. 16 shows the relative mass distribution in the system for the three scenarios. Only the gaseous cooling cases are included in the 
TABLE XV

PERFormanCE METRICS, OPTIMISTIC SCENARIO $(\mathrm{O}), j_{\text {cell }}$, max $=0.9$.

\begin{tabular}{|c|c|c|c|c|c|}
\hline \multirow[b]{3}{*}{ Metric } & \multirow[b]{3}{*}{ Unit } & \multicolumn{2}{|c|}{$\begin{array}{c}\text { Direct drive } \\
\left(\mathrm{n}_{\mathrm{SCM}}=1200 \mathrm{rpm}\right)\end{array}$} & \multicolumn{2}{|c|}{$\begin{array}{c}\text { With gear } \\
\left(\mathrm{n}_{\mathrm{SCM}}=3500 \mathrm{rpm}\right)\end{array}$} \\
\hline & & $\mathrm{O} 1$ & $\mathrm{O} 2$ & $\mathrm{O} 3$ & $\mathrm{O} 4$ \\
\hline & & $\begin{array}{c}\text { Gaseous } \\
\text { cooling }\end{array}$ & $\begin{array}{c}\text { Two-phase } \\
\text { cooling }\end{array}$ & $\begin{array}{c}\text { Gaseous } \\
\text { cooling }\end{array}$ & $\begin{array}{c}\text { Two-phase } \\
\text { cooling }\end{array}$ \\
\hline$m_{t o t}$ & $\mathrm{~kg}$ & 2625 & 2618 & 2514 & 2508 \\
\hline$P T W_{t o t}$ & $\mathrm{~kW} / \mathrm{kg}$ & 1.56 & 1.57 & 1.63 & 1.63 \\
\hline$\eta_{t o t, a v g}$ & $\%$ & 45.36 & 45.38 & 45.13 & 45.14 \\
\hline$T_{S C M, \max }$ & $\mathrm{K}$ & 28.7 & 22.2 & 28.8 & 22.2 \\
\hline$T_{H T S, \max }$ & K & 29.4 & 22.2 & 29.5 & 22.2 \\
\hline$T_{D C A C, \max }$ & $\mathrm{K}$ & 45.2 & 22.2 & 45.3 & 22.2 \\
\hline$T_{D C D C, \max }$ & $\mathrm{K}$ & 123.7 & 83.2 & 123.9 & 83.2 \\
\hline
\end{tabular}

TABLE XVI

Performance Metrics, CONSERVATIVE SCENARIO (C), $j_{\text {cell }, \text { max }}=$ 0.5 .

\begin{tabular}{|c|c|c|c|c|c|}
\hline \multirow[b]{3}{*}{ Metric } & \multirow[b]{3}{*}{ Unit } & \multicolumn{2}{|c|}{$\begin{array}{c}\text { Direct drive } \\
\left(\mathrm{n}_{\mathrm{SCM}}=1200 \mathrm{rpm}\right)\end{array}$} & \multicolumn{2}{|c|}{$\begin{array}{c}\text { With gear } \\
\left(\mathrm{n}_{\mathrm{SCM}}=3500 \mathrm{rpm}\right)\end{array}$} \\
\hline & & $\mathrm{C} 1$ & $\mathrm{C} 2$ & C3 & $\mathrm{C} 4$ \\
\hline & & $\begin{array}{l}\text { Gaseous } \\
\text { cooling }\end{array}$ & $\begin{array}{c}\text { Two-phase } \\
\text { cooling }\end{array}$ & $\begin{array}{l}\text { Gaseous } \\
\text { cooling }\end{array}$ & $\begin{array}{c}\text { Two-phase } \\
\text { cooling }\end{array}$ \\
\hline$m_{t o t}$ & $\mathrm{~kg}$ & 14033 & 13975 & 13771 & 13710 \\
\hline$P T W_{\text {tot }}$ & $\mathrm{kW} / \mathrm{kg}$ & 0.29 & 0.29 & 0.30 & 0.30 \\
\hline$\eta_{t o t, a v g}$ & $\%$ & 33.13 & 33.18 & 32.56 & 32.61 \\
\hline$T_{S C M, \max }$ & $\mathrm{K}$ & 78.4 & 35.1 & 78.3 & 35.0 \\
\hline$T_{H T S, \max }$ & $\mathrm{K}$ & 84.2 & 41.0 & 84.1 & 40.8 \\
\hline$T_{D C A C, \max }$ & $\mathrm{K}$ & 151.1 & 113.1 & 150.8 & 112.9 \\
\hline$T_{D C D C, \max }$ & K & 265.7 & 232.7 & 265.5 & 232.5 \\
\hline
\end{tabular}

figure, since changing to two-phase hydrogen cooling hardly impacts the component weights.

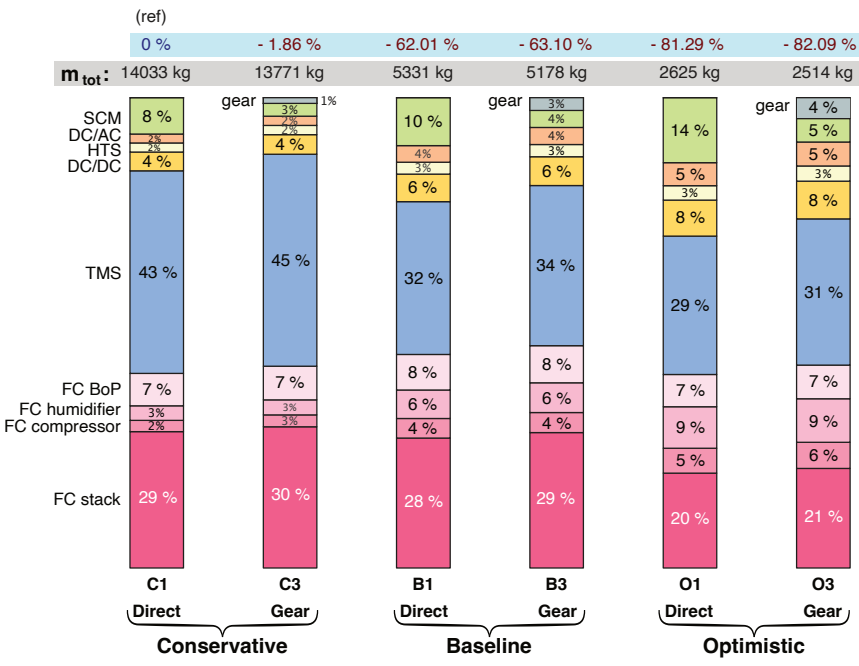

Fig. 16. Mass distribution for simulation cases with gaseous hydrogen cooling. Two-phase hydrogen cooling yields nearly identical results.

The TMS and the FC stack are the two dominating components in all scenarios. In the Optimistic scenario, the electrical components comprise $25-30 \%$ of the total system mass, compared to $12-16 \%$ for the Conservative scenario.

\section{E. Case S1: Sensitivity to SCM Parameters}

It is of interest to see how the SCM parameters impact the total performance of the cryo-electric architecture. Therefore,
TABLE XVII

MATRIX OF TARGETS MET FOR THE BASELINE AND OPTIMISTIC SCENARIOS. THE TARGET VALUES COME FROM TABLE I. EACH CASE NO. IS DESCRIBED IN TABLE XIII

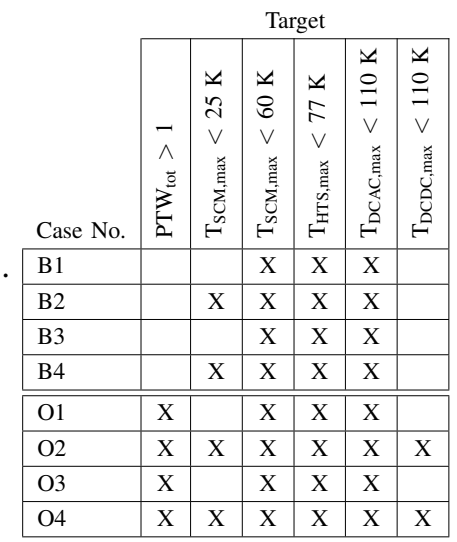

a sensitivity analysis is performed around the Baseline B1 case. Here, each of the parameters from Table $\mathrm{V}$ are varied separately, while all the remaining parameters are kept at their Baseline values. Table XVIII summarizes the parameter variations, where reference values from case $B l$ are written in boldface.

TABLE XVIII

SCM PARAMETER VARIATION IN SENSITIVITY STUDY S1

\begin{tabular}{ll}
\hline \hline Parameter & Values \\
\hline$T T W_{S C M}[\mathrm{Nm} / \mathrm{kg}]$ & $30,45, \mathbf{6 0}, 75,90$ \\
$\eta_{S C M, c}[\%]$ & $99.00,99.25, \mathbf{9 9 . 5 0}, 99.75,99.90$ \\
$\eta_{S C M, w}[\%]$ & $98.00,98.50, \mathbf{9 9 . 0 0}, 99.75,99.90$ \\
$P F_{S C M}[-]$ & $0.75,0.82, \mathbf{0 . 8 9}, 0.92,0.95$ \\
Gear & No gear, Gear included \\
\hline \hline
\end{tabular}

Fig. 17 shows the impact of varying the SCM parameters individually. Changes in $P T W_{t o t}, \eta_{t o t}$, and $T_{S C M, \max }$ are shown in each of the three plots. The TTW ratio has been excluded from plots $b$ and $c$ since it has no impact on the outcome.

The main observations from the plot are that the only factors that have any significant impact on the PTW of the total system, $P T W_{t o t}$ are the torque density of the SCM, $T T W_{S C M}$, and whether a gear is used between the SCM and the propeller.

The average total efficiency of the system (plot b), $\eta_{t o t, a v g}$ is hardly impacted by the power factor of the motor, whereas the gear and the cold and warm efficiencies, $\eta_{S C M, c}$ and $\eta_{S C M, h}$ show some impact. It should be noted that the efficiencies span over a relatively large range in this study. The gain in total average system efficiency is approximately 0.4 percentage point for each percentage point improvement in $\eta_{S C M, c}$ or $\eta_{S C M, w}$.

In this case (gaseous cooling), the maximum hydrogen temperature, $T_{S M C, \max }$ in the SCM is highly dependent on the SCM's cold efficiency. This can be seen in plot c. $T_{S M C, \max }$ is reduced by approximately $65 \mathrm{~K}$ per percentage point improvement in $\eta_{S C M, c}$. Furthermore, $T_{S M C, \max }$ is practically insensitive to changes in the other parameters. 
(a)

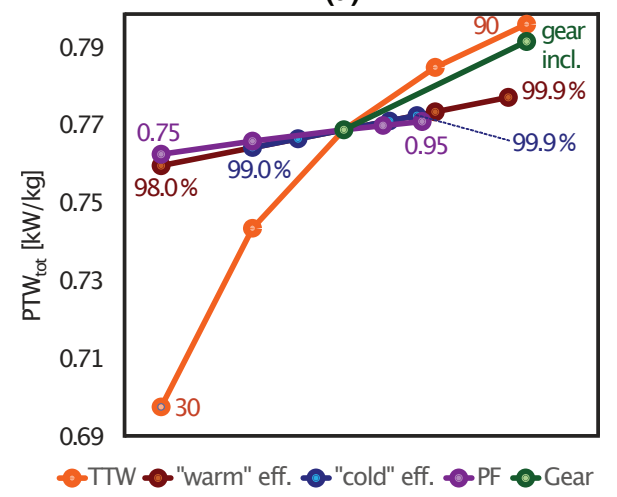

(b)

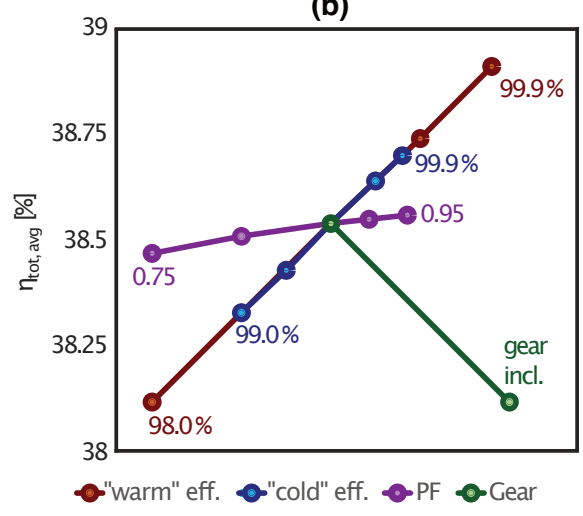

(c)

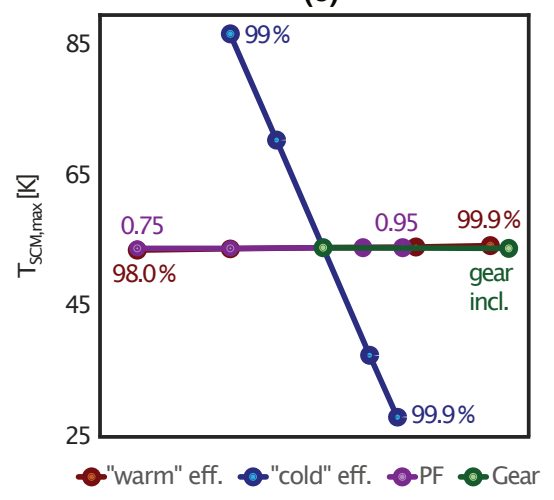

Fig. 17. SCM parameters' impact on (a): $\mathrm{PTW}_{\text {tot }}$, (b): $\eta_{\text {tot,avg }}$, and (c): $\mathrm{T}_{\mathrm{SCM} \text {,max }}$

\section{CONCLUSION}

This paper has investigated the feasibility of using liquid hydrogen $\left(\mathrm{LH}_{2}\right)$ fuel directly for cryogenic cooling of superconductors and other cooling purposes in a next-generation PEMFC-driven aircraft. Furthermore, it has been investigated if system power densities of $1 \mathrm{~kW} / \mathrm{kg}$ or better are achievable for such architectures, which inevitably would increase the scalability for widescale implementation of zero-emission aviation in the future. As a point of reference, direct burning of hydrogen in $\mathrm{H}_{2}$ combustion engines yields propulsion power density beyond $3.3 \mathrm{~kW} / \mathrm{kg}$ but has the drawback of the climate impact of non- $\mathrm{CO}_{2}$ emissions [2].

Due to the low TRL of the technology investigated, performance parameters have been projected to a 2035 scenario. To account for the inevitable uncertainties in making predictions about the future, the study has operated with three different scenarios when projecting the performance parameters of the components.

The interaction between the PEMFC, the hydrogen massflow, the cooling circuits, and the mission conditions is complex. The cryo-electric concept represents a radical technological challenge. Therefore, it is crucial to understand how this system functions as a whole and the conditions that each of the components are subjected to. To this end, a holistic model has been developed where the aim has been to do a complete system analysis over the full mission of a regional aircraft.

The results from the simulated scenarios show that the goal of a system power density exceeding $1 \mathrm{~kW} / \mathrm{kg}$ can indeed be achieved. However, it requires that the technology development moves toward the optimistic scenario, where system power densities exceeding $1.5 \mathrm{~kW} / \mathrm{kg}$ can be achieved.

It is also possible for each component to stay within the defined cryogenic temperature limits. The DC/DC converter has proven most difficult to maintain within the temperature limit of $110 \mathrm{~K}$. This is because it has been placed at the warm end of the cryogenic cooling loop in the simulated configurations. For the DC/DC converter to be properly cooled, it is required that the efficiencies of the cryogenic components approach the values set in the optimistic scenario and that liquid hydrogen is employed for cooling. All other components are sufficiently cooled in the baseline and optimistic scenarios, but some configurations require that REBCO superconductors are to be used in the $\mathrm{SCM}$, since the target limit for $\mathrm{MgB}_{2}$ is exceeded.

In addition to the results mentioned above, it has also been shown how the hydrogen temperatures reach maximum values at the final stage of the mission where the system power is low. Conversely, the temperatures are very near their minimum values at peak load. This underlines the importance of doing a full mission analysis when the system performance is evaluated.

The authors have identified several areas where further investigation and model refinement would be of great interest.

1) It would be very valuable to study the impact of adding a battery bank in the system. Even though batteries are heavy, there can be net synergies in using them to reduce the peak load of the PEMFC since this will drive down PEMFC and TMS size and improve the system efficiency.

2) The stoichiometric ratio on the anode will also have a direct impact on the hydrogen temperatures. Increasing this ratio will have a negative effect on the fuel economy, but there are potential benefits in using it actively to control the temperatures in the cryogenic loop. This should be investigated for operation at light load but also for potential fault scenarios. Unlike cryocoolers, a $\mathrm{LH}_{2}$ tank has a large overcapacity in terms of cryogenic cooling.

3) Generally, all component models can improve from further expansion and refinement. The TMS model should be a priority, given its large relative mass and notional design basis.

\section{REFERENCES}

[1] M. Schröder, F. Becker, J. Kallo, and C. Gentner, "Optimal operating conditions of pem fuel cells in commercial aircraft," International Journal of Hydrogen Energy, 2021.

[2] J. K. Nøland, "Hydrogen electric airplanes: A disruptive technological path to clean up the aviation sector," IEEE Electrific. Mag., vol. 9, no. 1, pp. 92-102, 2021.

[3] Y. Tao, J. Qiu, S. Lai, X. Zhang, and G. Wang, "Collaborative planning for electricity distribution network and transportation system considering hydrogen fuel cell vehicles," IEEE Trans. Transport. Electrific., vol. 6, no. 3, pp. 1211-1225, 2020.

[4] C. Sabillon, B. N. Singh, and B. Venkatesh, "Technoeconomic models for the optimal inclusion of hydrogen trains in electricity markets," IEEE Trans. Transport. Electrific., vol. 5, no. 3, pp. 758-768, 2019. 
[5] A. Haxhiu, A. Abdelhakim, S. Kanerva, and J. Bogen, "Electric power integration schemes of the hybrid fuel cells and batteriesfed marine vessels - an overview," IEEE Trans. Transport. Electrific., pp. 1-1, 2021.

[6] T. C. Cano, I. Castro, A. Rodríguez, D. G. Lamar, Y. F. Khalil, L. Albiol-Tendillo, and P. Kshirsagar, "Future of electrical aircraft energy power systems: An architecture review," IEEE Trans. Transport. Electrific., vol. 7, no. 3, pp. 1915-1929, 2021.

[7] E. Sayed, M. Abdalmagid, G. Pietrini, N.-M. Sa'adeh, A. D. Callegaro, C. Goldstein, and A. Emadi, "Review of electric machines in more-/hybrid-/turbo-electric aircraft," IEEE Trans. Transport. Electrific., vol. 7, no. 4, pp. 2976-3005, 2021

[8] C. E. Jones, P. J. Norman, G. M. Burt, C. Hill, G. Allegri, J. M. Yon, I. Hamerton, and R. S. Trask, "A route to sustainable aviation: A roadmap for the realization of aircraft components with electrical and structural multifunctionality," IEEE Trans. Transport. Electrific., vol. 7, no. 4, pp. 3032-3049, 2021

[9] C. E. Jones, P. J. Norman, S. J. Galloway, M. J. Armstrong, and A. M. Bollman, "Comparison of candidate architectures for future distributed propulsion aircraft," IEEE Transactions on Applied Superconductivity, vol. 26, no. 6, pp. 1-9, 2016

[10] M. Boll, M. Corduan, S. Biser, M. Filipenko, Q. H. Pham, S. Schlachter, P. Rostek, and M. Noe, "A holistic system approach for short range passenger aircraft with cryogenic propulsion system," Superconductor Science and Technology, vol. 33, no. 4 , p. 044014,2020

[11] F. Berg, J. Palmer, P. Miller, M. Husband, and G. Dodds, "Hts electrical system for a distributed propulsion aircraft," IEEE Transactions on Applied Superconductivity, vol. 25, no. 3, pp. $1-5,2015$.

[12] M. Filipenko, L. Kühn, T. Gleixner, M. Thummet, M. Lessmann, D. Möller, M. Böhm, A. Schröter, K. Häse, J. Grundmann et al., "Concept design of a high power superconducting generator for future hybrid-electric aircraft," Superconductor Science and Technology, vol. 33, no. 5, p. 054002, 2020

[13] I. Barnola, D. Freeman, P. Cheetham, S. Yang, C. H. Kim, and S. Pamidi, "Exploring options for integrated cryogenic circulation loop of superconducting power devices on electric aircraft," in 2019 AIAA/IEEE Electric Aircraft Technologies Symposium (EATS). IEEE, 2019, pp. 1-8.

[14] C. Wright Electric. (2021) Wright spirit energy storage discussion paper. [Online]. Available: https://docsend.com/view/faijiijzkvqdecjg

[15] B. Jux, S. Foitzik, and M. Doppelbauer, "A standard mission profile for hybrid-electric regional aircraft based on web flight data," in 2018 IEEE International Conference on Power Electronics, Drives and Energy Systems (PEDES). IEEE, 2018, pp. $1-6$.

[16] M. Cavcar, "The international standard atmosphere (isa)," Anadolu University, Turkey, vol. 30, no. 9, pp. 1-6, 2000.

[17] P. D. A. S. (PDAS). (2021) The us defense department non-standard atmospheres. [Online]. Available: https://www.pdas.com/milstd210.html

[18] J. M. Rheaume, M. Macdonald, and C. E. Lents, "Commercia hybrid electric aircraft thermal management system design, simulation, and operation improvements," in 2019 AIAA/IEEE Electric Aircraft Technologies Symposium (EATS). IEEE, 2019, pp. 1-23.

[19] E. W. Lemmon, M. O. McLinden, and D. G. Friend 'Thermophysical properties of fluid systems' in NIST chemistry webbook, NIST standard reference database number 69, Eds. P.J. Linstrom and W.G. Mallard. Gaithersburg MD, 20899. [Online]. Available: https://doi.org/10.18434/T4D303

[20] G. V. Brown, A. F. Kascak, B. Ebihara, D. Johnson, B. Choi, M. Siebert, and C. Buccieri, "Nasa glenn research center program in high power density motors for aeropropulsion," National Aeronautics and Space Administration Cleveland, Tech. Rep., 2005.

[21] N. E. Anderson, S. H. Loewenthal, and J. D. Black, "An analytical method to predict efficiency of aircraft gearboxes," 1986.

[22] R. Jansen, C. Bowman, and A. Jankovsky, "Sizing power components of an electrically driven tail cone thruster and a range extender," in 16th AIAA Aviation Technology, Integration, and Operations Conference, 2016, p. 3766.

[23] R. Jansen, C. Bowman, A. Jankovsky, R. Dyson, and J. Felder, "Overview of nasa electrified aircraft propulsion (eap) research for large subsonic transports," in 53rd AIAA/SAE/ASEE joint propulsion conference, 2017, p. 4701.
[24] H. D. Kim, G. V. Brown, and J. L. Felder, "Distributed turboelectric propulsion for hybrid wing body aircraft," in 9th International Powered Lift Conference, London, United Kingdom. Citeseer, 2008

[25] F. Berg, J. Palmer, P. Miller, and G. Dodds, "Hts system and component targets for a distributed aircraft propulsion system," IEEE Transactions on Applied Superconductivity, vol. 27, no. 4, pp. 1-7, 2017.

[26] B. Aigner, M. Nollmann, and E. Stumpf, Design of a hybrid electric propulsion system within a preliminary aircraft design software environment. Deutsche Gesellschaft für Luft-und Raumfahrt-Lilienthal-Oberth eV, 2018.

[27] J. Rheaume and C. E. Lents, "Design and simulation of a commercial hybrid electric aircraft thermal management system," in 2018 AIAA/IEEE Electric Aircraft Technologies Symposium, 2018 , p. 4994

[28] H. Kellermann, M. Lüdemann, M. Pohl, and M. Hornung, "Design and optimization of ram air-based thermal management systems for hybrid-electric aircraft," Aerospace, vol. 8, no. 1, p. 3, 2021.

[29] J. W. Chapman, S. L. Schnulo, and M. P. Nitzsche, "Development of a thermal management system for electrified aircraft," in AIAA Scitech 2020 Forum, 2020, p. 0545.

[30] C. E. Lents, L. W. Hardin, J. Rheaume, and L. Kohlman, "Parallel hybrid gas-electric geared turbofan engine conceptual design and benefits analysis," in 52nd AIAA/SAE/ASEE Joint Propulsion Conference, 2016, p. 4610.

[31] H. Kellermann, A. L. Habermann, and M. Hornung, "Assessment of aircraft surface heat exchanger potential," Aerospace, vol. 7, no. 1 , p. $1,2020$.

[32] M. Warncke, S. Fahlbusch, and K. Hoffmann, "Dc/dc-converter for fuel cell integration in more electric aircraft applications," in 2017 19th European Conference on Power Electronics and Applications (EPE'17 ECCE Europe). IEEE, 2017, pp. P-1.

[33] B. Łukasik, "Turboelectric distributed propulsion system as a future replacement for turbofan engines," in Turbo Expo: Power for Land, Sea, and Air, vol. 50770. American Society of Mechanical Engineers, 2017, p. V001T01A017.

[34] F. Barbir, PEM fuel cells: theory and practice. Academic press, 2012.

[35] A. Thirkell, "Systems study for fuel cell powered more electric aircraft," Ph.D. dissertation, Loughborough University, 2021.

[36] K. Jiao, J. Xuan, Q. Du, Z. Bao, B. Xie, B. Wang, Y. Zhao, L. Fan, H. Wang, Z. Hou et al., "Designing the next generation of proton-exchange membrane fuel cells," Nature, vol. 595, no. 7867, pp. 361-369, 2021.

[37] J. C. Kurnia, A. P. Sasmito, and T. Shamim, "Advances in proton exchange membrane fuel cell with dead-end anode operation: A review," Applied Energy, vol. 252, p. 113416, 2019.

[38] H. Struchtrup, Thermodynamics and energy conversion. Springer, 2014.

[39] A. Lombardi, D. Ferrari, and L. Santos, "Aircraft air inlet design optimization via surrogate-assisted evolutionary computation," in International Conference on Evolutionary Multi-Criterion Optimization. Springer, 2015, pp. 313-327.

[40] Y. Wang, J. Li, Q. Tao, M. H. Bargal, M. Yu, X. Yuan, and C. Su, "Thermal management system modeling and simulation of a full-powered fuel cell vehicle," Journal of Energy Resources Technology, vol. 142, no. 6, 2020. 